\title{
Phylogeny and biogeography of a shallow water fish clade (Teleostei: Blenniiformes)
}

Hsiu-Chin Lin ${ }^{1,2^{*}}$ and Philip A Hastings ${ }^{1}$

\begin{abstract}
Background: The Blenniiformes comprises six families, 151 genera and nearly 900 species of small teleost fishes closely associated with coastal benthic habitats. They provide an unparalleled opportunity for studying marine biogeography because they include the globally distributed families Tripterygiidae (triplefin blennies) and Blenniidae (combtooth blennies), the temperate Clinidae (kelp blennies), and three largely Neotropical families (Labrisomidae, Chaenopsidae, and Dactyloscopidae). However, interpretation of these distributional patterns has been hindered by largely unresolved inter-familial relationships and the lack of evidence of monophyly of the Labrisomidae.

Results: We explored the phylogenetic relationships of the Blenniiformes based on one mitochondrial (COI) and four nuclear (TMO-4C4, RAG1, Rhodopsin, and Histone H3) loci for 150 blenniiform species, and representative outgroups (Gobiesocidae, Opistognathidae and Grammatidae). According to the consensus of Bayesian Inference, Maximum Likelihood, and Maximum Parsimony analyses, the monophyly of the Blenniiformes and the Tripterygiidae, Blenniidae, Clinidae, and Dactyloscopidae is supported. The Tripterygiidae is the sister group of all other blennies, and the Blenniidae is the sister group of the remaining blennies. The monophyly of the Labrisomidae is supported with the exclusion of the Cryptotremini and inclusion of Stathmonotus, and we elevate two subgenera of Labrisomus to establish a monophyletic classification within the family. The monophyly of the Chaenopsidae is supported with the exclusion of Stathmonotus (placed in the Stathmonotini) and Neoclinus and Mccoskerichthys (placed in the Neoclinini). The origin of the Blenniiformes was estimated in the present-day IndoPacific region, corresponding to the Tethys Sea approximately 60.3 mya. A largely Neotropical lineage including the Labrisomidae, Chaenopsidae and Dactyloscopidae (node IV) evolved around 37.6 mya when the Neotropics were increasingly separated from the IndoPacific, but well before the closure of the Tethys Sea.

Conclusions: Relationships recovered in this study are similar to those of earlier analyses within the Clinidae and Chaenopsidae, and partially similar within the Blenniidae, but tripterygiid relationships remain poorly resolved. We present the first comprehensive phylogenetic hypothesis for a monophyletic Labrisomidae with five tribes (Labrisomini, Mnierpini, Paraclinini, Stathmonotini and Starksiini). Global distributions of blenny genera included in our analysis support the evolution of a largely Neotropical clade whose closest relatives (clinids and cryptotremines) are temperate in distribution.
\end{abstract}

Keywords: Tripterygiidae, Blenniidae, Labrisomidae, Clinidae, Dactyloscopidae, Chaenopsidae, Neotropics, Tethys sea, Biogeography

\footnotetext{
* Correspondence: hsiuchinlin@gate.sinica.edu.tw

${ }^{1}$ Marine Biology Research Division, Scripps Institution of Oceanography,

University of California San Diego, La Jolla, CA 92093, USA

${ }^{2}$ Biodiversity Research Center, Academia Sinica, Taipei 115, Taiwan
} 


\section{Background}

The Blenniiformes comprises six families, 151 genera and nearly 900 species [1] of small teleost fishes closely associated with coastal benthic habitats. Although small, blennies often numerically dominate rocky reef ichthyofaunas [2-4]. Because of their abundance and the ease at which they can be observed, blennies have become convenient models for the study of ecology and behavior [5]. Blennies also provide an unparalleled opportunity for marine biogeography because they include the globally distributed families Tripterygiidae and Blenniidae, the temperate Clinidae, and three families (Labrisomidae, Chaenopsidae, and Dactyloscopidae) largely restricted to the Neotropics [6]. The breakup of the Tethys Sea [7], formation of the Central America Isthmus [8], and climate warming during the Pliocene [9] have been suggested as important historical events shaping the evolution and current distributional patterns of blennies. However, insights from these and other studies have been compromised by the absence of a well-resolved phylogeny for the group.

The history of blenniiform classification has been reviewed by several researchers (e.g. [1,10-12]). Members of the currently recognized families Tripterygiidae, Blenniidae, Labrisomidae, Clinidae and Chaenopsidae are consistently included, but other families have been added depending on the definition of "true" blennies [11,13-16]. A widely accepted concept of a monophyletic Blenniiformes as the "tropical" blenny families (= Blenniicae sensu Hubbs, 1952; [14]) was revisited by Springer [11] and, based on morphological characters, formalized to include the above five families and the sand stargazers, Dactyloscopidae, as hypothesized earlier by Regan [16]. Springer's Blennioidei, termed the Blenniiformes by Wiley and Johnson [17], shares several unique morphological features including presence of a bean-shaped pelvis, a reduced branchial apparatus, proximal pectoral-fin radials longer than wide, unbranched pectoral-fin rays, relatively simple caudal-fin morphology, 0-2 spines and simple segmented rays in the anal-fin, and no neural spine on the first vertebra $[11,18]$.

Inter-familial relationships of blenniiforms have remained largely unresolved because of conflicting morphological and molecular evidence [1]. It is generally agreed that the Tripterygiidae is the sister group of all other blennies, based on these groups having unbranched dorsal- and pectoral-fin rays (branched in most triplfins), no ctenoid scales as in triplefins, and roofed sensory canal bones (unroofed in triplefins) [11]. It has also been hypothesized that the Blenniidae is the sister group of the remaining blennies based on several features of the dorsal gill-arches and associated muscles [19]. However, a consensus has not been reached regarding relationships among the Clinidae, Chaenopsidae, Dactyloscopidae and Labrisomidae.
The monophyly of the first three of these families has been supported by morphological synapomorphies [11]. However, the Labrisomidae includes generalized blennies that do not fall into the other relatively well-defined families and no synapomorphies have been identified for this group [11] other than one possible reductive character [20]. Labrisomids have long been considered to be closely related to the Clinidae (e.g. [14]) and included in that family by some authors (e.g. [21]). In addition, the relationships of the Dactyloscopidae to other blennies, the most recent major lineage to be added to the Blenniiformes [11], have been evaluated based only on dorsal gill-arch anatomy [19]. Thus, dactyloscopids have been placed in an unresolved polytomy along with the Clinidae, Labrisomidae and Chaenopsidae [1]. Two molecular studies have attempted to resolve the phylogenetic relationships among the blenny families $[9,22]$. These provided inconsistent phylogenetic hypotheses, although both questioned the monophyly of the Labrisomidae and the Chaenopsidae.

Recently, the systematics of blennies was thoroughly reviewed, providing convenient reference points: the Labrisomidae, Clinidae, Chaenopsidae, and Dactyloscopidae by Hastings and Springer [1], the Blenniidae by Hastings and Springer [23] and the Tripterygiidae by Fricke [24]. In addition, studies on higher-level relationships of fishes based on morphology and multiple genetic markers have suggested a close relationship between blennies and clingfishes (Gobiesocidae) [19,25-30], jawfishes (Opistognathidae) [31,32], and basslets (Grammatidae) [31,33-35] within the recently recognized Ovalentaria [32]. In the present study, we attempt to reconstruct the phylogenetic relationships of the Blenniiformes with significantly broader taxon sampling (150 blenniiform species), substantially more genetic information (one mitochondrial and four nuclear markers), and more strategic outgroup representation than in previous studies.

\section{Results}

\section{Sequence analysis}

The dataset comprises 150 blenniiforms, six gobiesocids, one opistognathid, and one grammatid species as terminal taxa scored for 3,562 bp including 570 bp in COI, 421 bp in TMO-4C4, 1,506 bp in RAG1, 737 bp in Rhodopsin, and 328 bp in Histone H3 (Table 1 and Additional file 1: Table S1). Genetic markers unable to be amplied and sequenced (14\% in COI, $15 \%$ in TMO-4C4, $6 \%$ in RAG1 and Rhodopsin, and $4 \%$ in Histone H3) were treated as missing data for all phylogenetic analyses. The alignments of COI, Rhodopsin and Histone H3 were unambiguous, but several indels with multiples of three were observed in TMO-4C4 and RAG1, especially in species of the Tripterygiidae. The aligned data matrix is available in TreeBASE (http://purl.org/phylo/treebase/phylows/study/ 
Table 1 Currently recognized lineages of six families of the Blenniiformes $[1,23,24,36]$

\begin{tabular}{lll}
\hline $\begin{array}{l}\text { Family (total genera/ } \\
\text { total species) }\end{array}$ & $\begin{array}{l}\text { Lineage (total genera/ } \\
\text { sampled genera) }\end{array}$ & $\begin{array}{l}\text { Genera (total species/ } \\
\text { sampled species) }\end{array}$ \\
\hline Tripterygiidae (32/164) & & \\
& Notoclinini (2/0) & \\
& Trianectini (5/0) & \\
& Norfolkiini (4/2) & Cremnochorites (1/1) \\
& Lepidonectes (3/1) \\
& Tripterygiini (8/4) & Axoclinus (6/3) \\
& Crocodilichthys (1/1) & Enneanectes (8/7) \\
& Enneapterygius (53/3) \\
& Forsterygiini (5/0) & \\
& Kelcogrammini (3/1) & Helcogramma (39/2) \\
& Blennodontini (3/0) &
\end{tabular}

Blenniidae (57/387)

$\begin{array}{ll}\text { Blenniini (2/0) } & \\ \text { Nemophini (5/4) } & \text { Meiacanthus (25/1) } \\ & \text { Petroscrites (11/1) } \\ & \text { Plagiotremus (11/3) } \\ & \text { Xiphasia (2/1) } \\ \text { Omobranchini (7/1) } & \text { Omobranchus (21/2) } \\ \text { Phenablenniini (1/0) } & \\ \text { Parablenniini (14/2) } & \text { Hypsoblennius (14/6) } \\ & \text { Parablennius (27/1) } \\ \text { Salariini-Salarias } & \text { Alticus (10/1) } \\ \text { group (20/12) } & \text { Andamia (7/2) } \\ & \text { Atrosalarias (3/1) } \\ & \text { Blenniella (9/2) } \\ & \text { Cirripectes (22/5) } \\ & \text { Ecsenius (53/4) } \\ & \text { Entomacrodus (25/4) } \\ \text { Salariini-Rhabdoblennius } & \text { Rhabdoblennius (14/3) } \\ \text { group (8/1) } & \text { Nannosalarias (1/1) } \\ & \text { Ophioblennius (5/2) } \\ & \text { Praealticus (13/5) } \\ & \text { Salarias (13/2) } \\ & \\ & \\ & \\ & \\ & \\ & \end{array}$

Labrisomidae (14/109)

$\begin{array}{ll}\text { Cryptotremini (4/3) } & \text { Alloclinus (1/1) } \\ & \text { Auchenionchus (3/1) } \\ & \text { Calliclinus (2/1) }\end{array}$

Table 1 Currently recognized lineages of six families of the Blenniiformes $[1,23,24,36]$ (Continued)

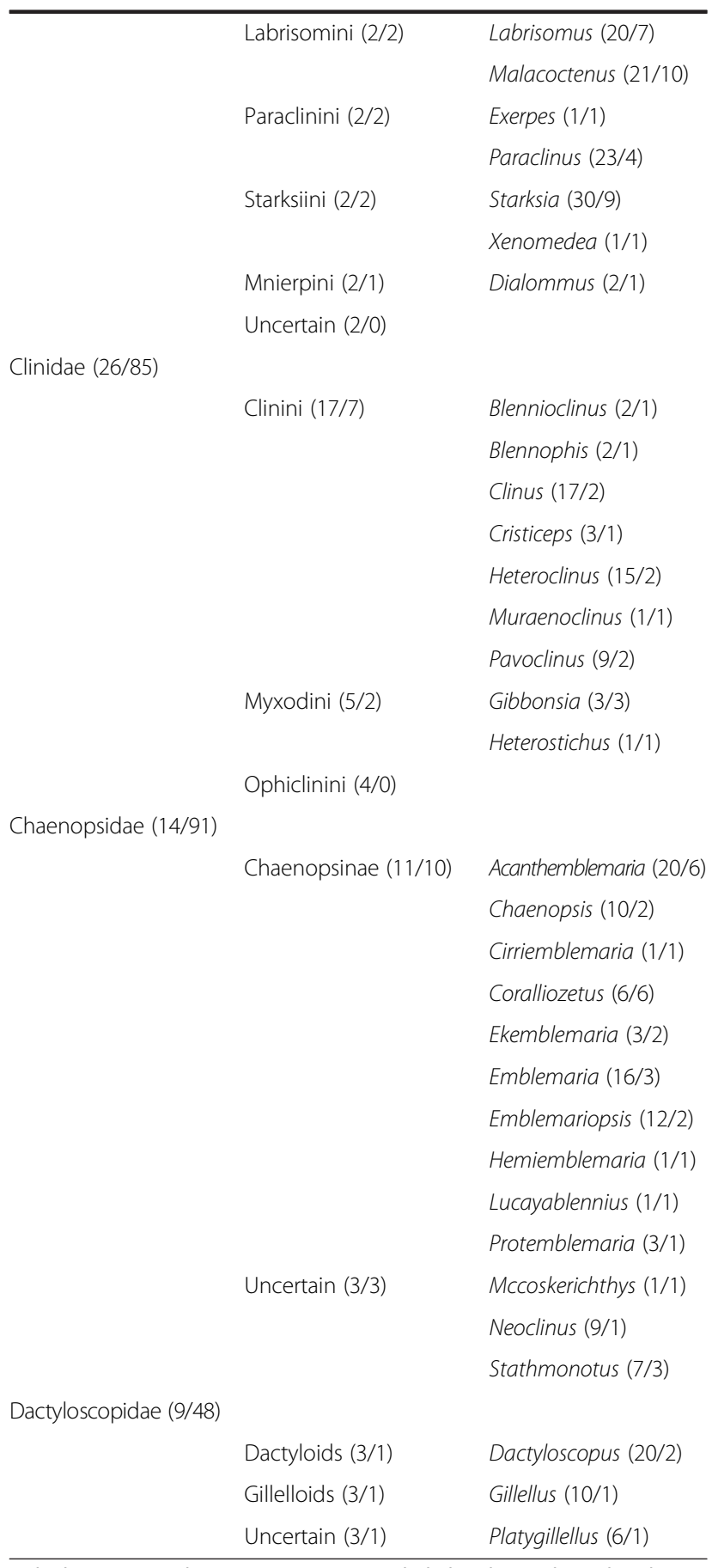

Only the genera with representative taxa included in this study are listed.

TB2:S14731). The GC content of the first codon across all markers ranged from $51.1 \%$ to $61.9 \%$, the second codon from $32.4 \%$ to $47.7 \%$, and the third codon from $39.2 \%$ to $84.0 \%$ (Table 2). The Chi-square test results of basefrequency homogeneity across taxa were significant for 
Table 2 Proportions of variable and parsimony informative characters, best nucleotide substitution model and parameters selected by jModelTest for each data partition

\begin{tabular}{|c|c|c|c|c|c|c|c|c|}
\hline Gene & $\begin{array}{l}\text { Codon } \\
\text { position }\end{array}$ & Length (bp) & $\mathrm{G}+\mathrm{C}(\%)$ & $\begin{array}{l}\text { Variable } \\
\text { characters }\end{array}$ & $\begin{array}{l}\text { Parsimony informative } \\
\text { characters }\end{array}$ & $\begin{array}{l}\text { Best model } \\
\text { by jModelTest }\end{array}$ & 1 & G \\
\hline \multirow[t]{2}{*}{ COI } & $1 s t+2 n d$ & 380 & $55.2 / 43.2$ & 74 (19.47\%) & $51(13.42 \%)$ & TIM3+I+G & 0.7510 & 0.4720 \\
\hline & $3 r d$ & 190 & 39.2 & $190(100 \%)$ & 189 (99.47\%) & $\mathrm{GTR}+\mathrm{G}$ & - & 0.3310 \\
\hline \multirow[t]{2}{*}{ TMO-4C4 } & $1 s t+2 n d$ & 280 & $59.0 / 32.4$ & $114(40.71 \%)$ & 79 (28.21\%) & $\mathrm{TIM} 3+\mathrm{I}+\mathrm{G}$ & 0.4190 & 0.4040 \\
\hline & $3 r d$ & 140 & 63.3 & 137 (97.86\%) & 135 (96.32\%) & $T V M+I+G$ & 0.0210 & 1.2690 \\
\hline \multirow[t]{2}{*}{ Rhod } & $1 s t+2 n d$ & 492 & $51.1 / 42.4$ & 66 (13.41\%) & 55 (11.18\%) & $\mathrm{TIM} 3+\mathrm{I}+\mathrm{G}$ & 0.8340 & 0.6190 \\
\hline & $3 r d$ & 245 & 76.9 & 176 (71.84\%) & $154(62.86 \%)$ & TVM+I+G & 0.2050 & 0.6940 \\
\hline \multirow[t]{2}{*}{ Rag1 } & $1 s t+2 n d$ & 1004 & $56.2 / 41.2$ & 307 (30.58\%) & 223 (22.21\%) & $\mathrm{GTR}+\mathrm{I}+\mathrm{G}$ & 0.5550 & 0.3760 \\
\hline & $3 r d$ & 502 & 66.9 & 455 (90.64\%) & 432 (86.06\%) & TPM2uf $+1+G$ & 0.0810 & 0.9380 \\
\hline \multirow[t]{2}{*}{ H3 } & $1 s t+2 n d$ & 218 & $61.9 / 47.7$ & 21 (9.63\%) & $9(4.13 \%)$ & $\mathrm{GTR}+\mathrm{I}+\mathrm{G}$ & 0.7270 & 0.1840 \\
\hline & $3 r d$ & 110 & 84.0 & 76 (69.09\%) & 65 (59.09\%) & $\mathrm{TIM} 2+\mathrm{I}+\mathrm{G}$ & 0.2570 & 0.7580 \\
\hline
\end{tabular}

I: proportion of invariant sites. G: gamma rate variation among sites.

the third codon position of COI, TMO-4C4, Rhodopsin and RAG1 ( $\mathrm{p}$ 0.005), but not significant for the remaining partitions.

Among the 3,562 bp, the alignment comprised 1,627 (45.68\%) variable sites, of which 1,392 (39.08\%) were parsimony informative. The sequences of the ten partitions provided a range of evolutionary information. The third codon position of all five markers provided significantly more parsimony information (59.09\% to $99.47 \%$ ) than the first and second positions (4.13\% to $28.21 \%)$. The third codon of the only mitochondrial marker (COI) had the highest proportion of variable characters (100\%) and the highest proportion of parsimony informative characters (99.47\%). The first and second codon positions of the nuclear marker Histone $\mathrm{H} 3$ had the lowest proportion of both variable characters (9.63\%) and parsimony informative characters $(4.13 \%)$.

\section{Phylogenetic relationships}

For the complete dataset, the score of the best ML trees found was -80231.7055 . Four equally parsimonious trees of 18,493 steps were returned with the MP analysis. Both ML- and MP-generated topologies based on the complete dataset are congruent with those from BI analysis with regard to the relationships at the family-, subfamily-, and tribe-levels. The recovered relationships of blenniiform clades based on maximum likelihood methods are summarized in Figure 1 and in detail in Figures 2, 3 and 4. The concatenated molecular data strongly support the monophylies of the Tripterygiidae (ML bootstrap value / MP bootstrap value / Bayesian posterior probability $=100 /$ 100/100), Blenniidae (99/100/100), Clinidae (90/55/100), Chaenopsidae sensu stricto (100/100/100), and Dactyloscopidae (99/100/100), as well as the monophyly of their sister group, the Gobiesocidae (100/100/100). The Tripterygiidae is the sister group of all other blenniiforms, and the Blenniidae is the sister group of all remaining blennies. Calliclinus geniguttatus (currently a labrisomid) is the sister group of a large clade that includes the Clinidae, Labrisomidae, Chaenopsidae and Dactyloscopidae (Figure 4).

In general, the relationships among triplefins were poorly resolved in all analyses (Figure 2). Relationships within the Blenniidae were, however, well resolved, with only a few discrepancies among analytical methods (Figure 3). The monophyly of all blenniid genera for which we sampled multiple species was well supported except that Alticus saliens was nested within Andamia, and Atrosalaris fuscus was nested within Salarias (Figure 3). The monophyly of each the four blenniid tribes included in our study (i.e., Parablenniini, Salariini, Nemophini, and Omobranchini) was well supported with the exception of the Salariini in the MP analysis (MP bootstrap value $=66)$. The two Blenniinae tribes Nemophini and Omobranchini were grouped together and were the sister group of the tribe Parablenniini. This entire clade was the sister group of the tribe Salariini.

Relationships among the remaining four families were well resolved in the shallower nodes, but less so in the deeper nodes (Figure 4). In general the pattern is the inclusion of low-diversity taxa as the sister group of larger monophyletic clades. These low-diversity groups include Calliclinus (Cryptotremini), Auchenionchus + Alloclinus (both currently Cryptotremini), and the "chaenopsids" Neoclinus and Mccoskerichthys. In addition to a monophyletic Clinidae, all three analytical methods recovered two diverse clades with moderate support values. These included the members of the Labrisomidae (node II) other than the Cryptotremini that together formed a monophyletic group with the inclusion of the genus Stathmonotus (currently considered a chaenopsid). The second lineage (node III) included the Dactyloscopidae plus the Chaenopsidae sensu stricto (i.e., excluding Stath monotus, Neoclinus and Mccoskerichthys). 


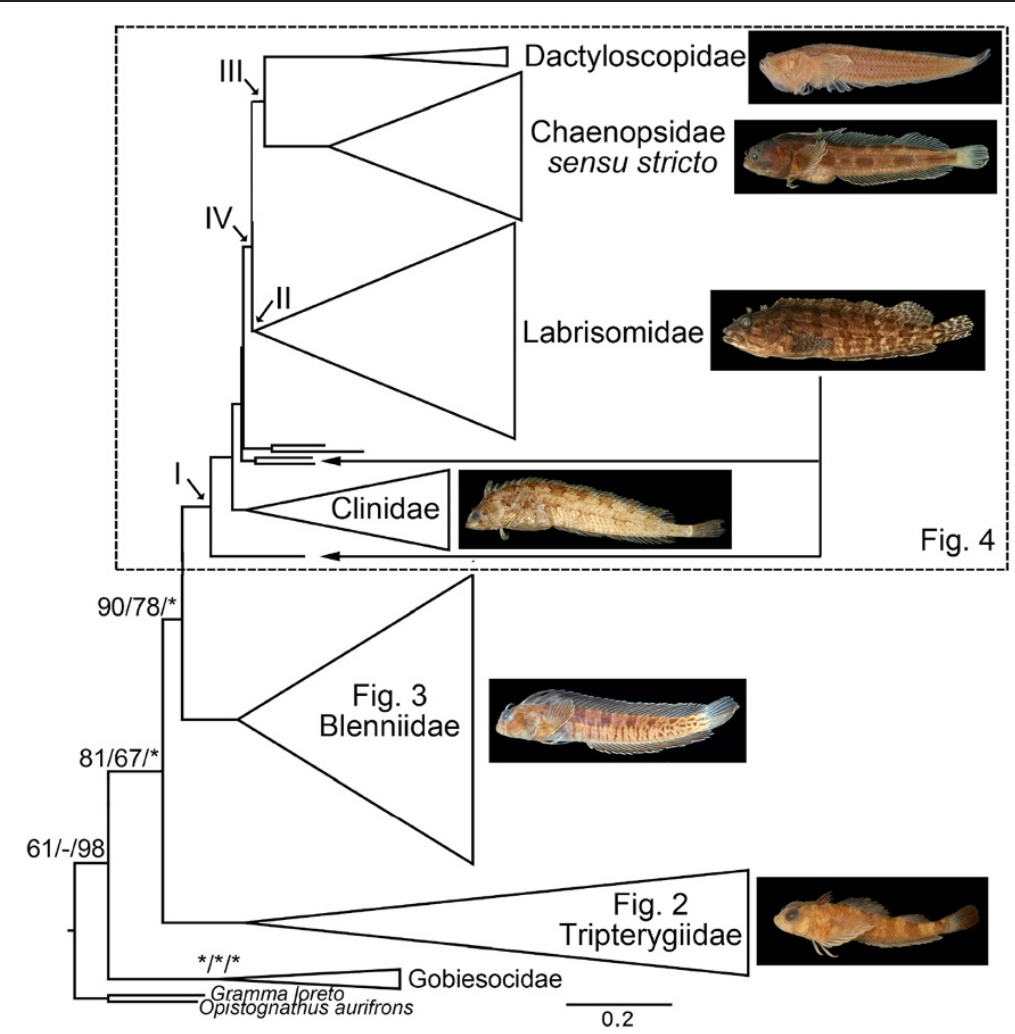

Figure 1 Phylogenetic relationships among major blenniiform clades based on Maximum Likelihood analysis. The supporting values of nodes (Maximum Likelihood bootstrap/Maximum Parsimony bootstrap/Bayesian posterior probability) were only shown if not in Figures 2, 3 and 4 where the phylogenetic relationships are shown in detail. ${ }^{*}=100 .--=$ not supported. Representative photos of the six blenniiform families are Enneanectes macrops (Tripterygiidae), Hypsoblennius striatus (Blenniidae), Myxodes ornatus (Clinidae), Labrisomus xanti (Labrisomidae), Acanthemblemaria hastingsi (Chaenopsidae), and Dactyloscopus lunaticus (Dactyloscopidae).

Within the labrisomid clade (node II; BI PP=74), BI recovered relationships with Dialommus (Mnierpini) as the sister group of two relatively large clades, the Paraclinini + Stathmonotus, and Starksiini + Labrisomini (Figure 4). Within the Paraclinini, the monotypic genus Exerpes was nested within the genus Paraclinus, while within the Starksiini, the monotypic genus Xenomedea was the sister group of a monophyletic Starksia (Figure 4). Within the Labrisomini, the genus Labrisomus was not monophyletic, but divided into two clades. One clade included the subgenus Labrisomus that was the sister group of the monophyletic genus Malacoctenus, while the other clade included all other sampled members of Labrisomus (Figure 4).

In the remaining large clade (node III; $\mathrm{BI} P \mathrm{P}=86$ ), the monophyletic Dactyloscopidae was the sister group of a monophyletic Chaenopsidae sensu stricto (i.e., exclusive of Stathmonotus, Neoclinus and Mccoskerichthys). Within the Chaenopsidae all currently recognized genera were recovered as monophyletic, and the genus Coralliozetus

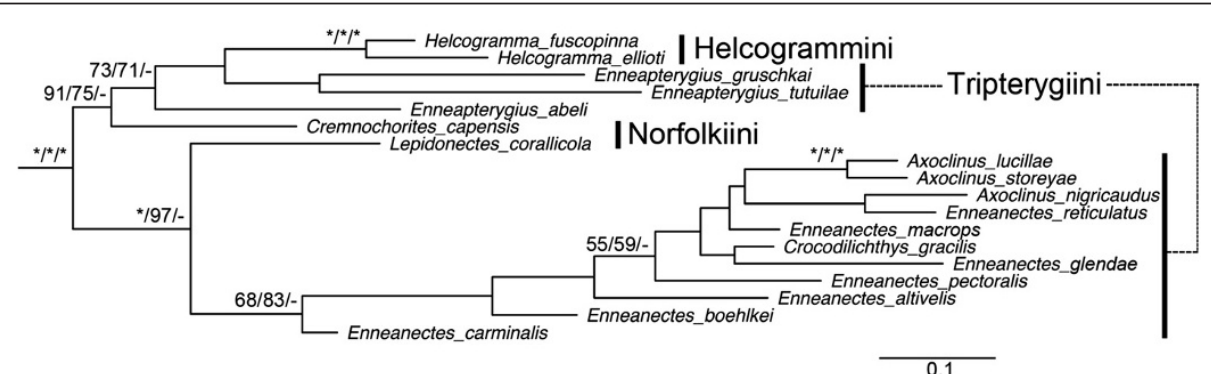

Figure 2 Phylogenetic relationships of the Tripterygiidae based on Maximum Likelihood analysis. Node supports are Maximum Likelihood bootstrap/Maximum Parsimony bootstrap/Bayesian posterior probability. ${ }^{*}=100$. - = not supported. 


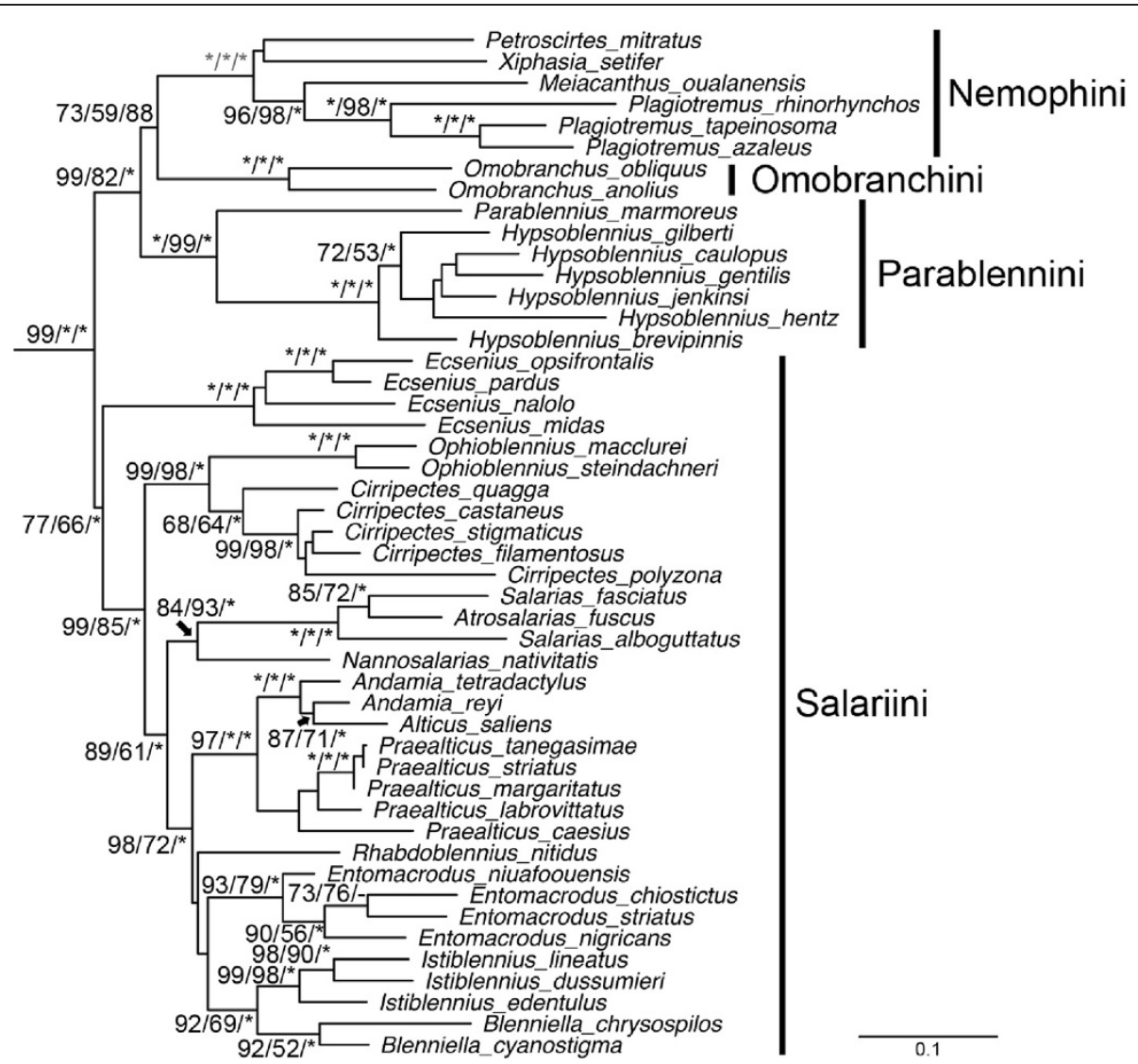

Figure 3 Phylogenetic relationships of the Blenniidae based on Maximum Likelihood analysis. Node supports are Maximum Likelihood bootstrap/Maximum Parsimony bootstrap/Bayesian posterior probability. ${ }^{*}=100$. - = not supported.

was the sister group of all other chaenopsids. That group included two large clades, one with Emblemariopsis, Protemblemaria and Cirriemblemaria, and another with Acanthemblemaria, Ekemblemaria, Hemiemblemaria, Em blemaria, Chaenopsis and Lucayablennius (Figure 4).

\section{Biogeography}

The divergence times of blenniiform lineages were estimated from the combined postburn-in trees and parameter values of the BEAST analyses (Additional file 2: Figure S1). The maximum clade credibility tree estimated from the posterior density was characterized by a large number of nodes supported with significant Bayesian posterior probabilities (data not shown) and the mean of the posterior density of the likelihood score was -786 78.5184 (95\% highest posterior densities [HPD]: - 78748.29 to -78607.9508$)$.

Mapping present day distributions of genera included in our study using BBM (Figure 5) and MP (Additional file 3: Figure S2) indicate: 1) an IndoPacific origin for the Blenniiformes with an estimated age of $60.3 \mathrm{my}$ (HPD: 28.2 to 95.9$)$; 2) multiple invasions of the Neotropics and/or temperate regions within the Tripterygiidae and
Blenniidae that occurred at a variety of times before the present; 3) a Neotropical origin of the clade including the Labrisomidae, Chaenopsidae and Dactyloscopidae (node IV) with an estimated age 37.6 my (HPD: 17.5 to 59.7 ); 4) primarily temperate origins for the intervening clades including the Clinidae and current members of the nonmonophyletic Cryptotremini.

\section{Discussion}

Families and inter-family relationships of the Blenniiformes

Although the monophyly of the Blenniiformes sensu Wiley and Johnson, 2009 [17] (= Blennioidei sensu Springer, 1993; [11]) has been questioned by some (e.g. [34]), our phylogenetic analysis found strong support for its monophyly in agreement with other recent molecular analyses (e.g. $[32,35])$. Blenniiform monophyly is also supported by seven morphological character complexes $[1,11,18]$. This lineage includes nearly 900 species allocated among six families and is the sister group of the Gobiesocidae (Figure 1), a relationship supported by six morphological characters, one of which is unique to this lineage [19].

Our study supports the monophyly of four of the six blenniiform families as currently construed. The mono- 


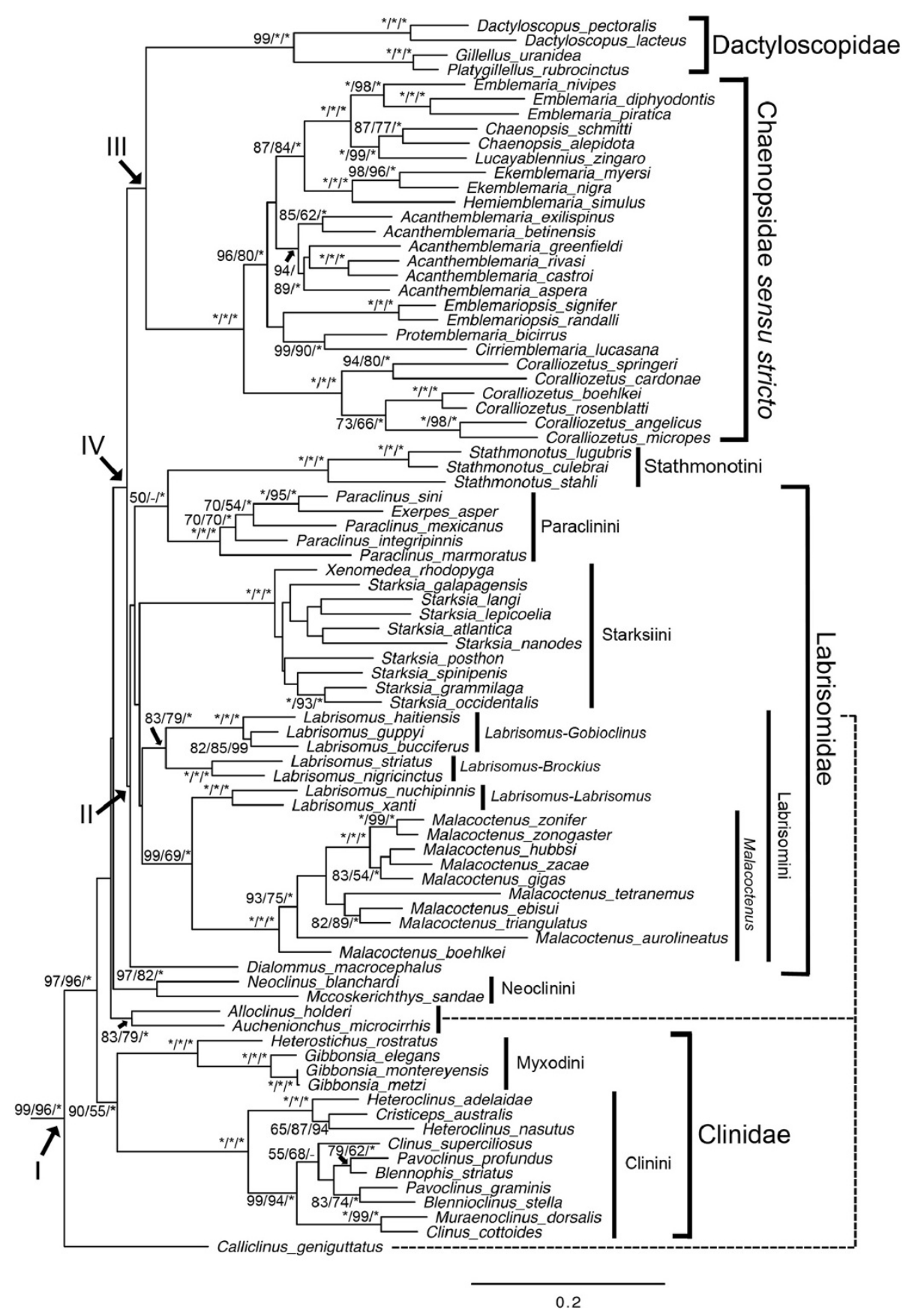

Figure 4 Phylogenetic relationships of the blenniiform species other than Tripterygiidae and Blenniidae based on Maximum Likelihood analysis. Node supports are Maximum Likelihood bootstrap/Maximum Parsimony bootstrap/Bayesian posterior probability. ${ }^{*}=100 .-$ - not supported.

phyly of the Tripterygiidae, Blenniidae, Clinidae and Dactyloscopidae are also well-supported by morphological synapomorphies $[1,11,23]$. The monophyly of the Chaenopsidae (sensu Hastings and Springer, 1994 [37]) and the Labrisomidae are, however, not supported in our analysis (see below).
Within the Blenniiformes, our study indicates that the Tripterygiidae is the sister group to the remaining blennies (Figure 1). This hypothesis was proposed by Springer [11] based on details of the fin rays, scales and cephalic sensory system, and subsequently supported by Springer and Orrell [19] based on details of the branchial 


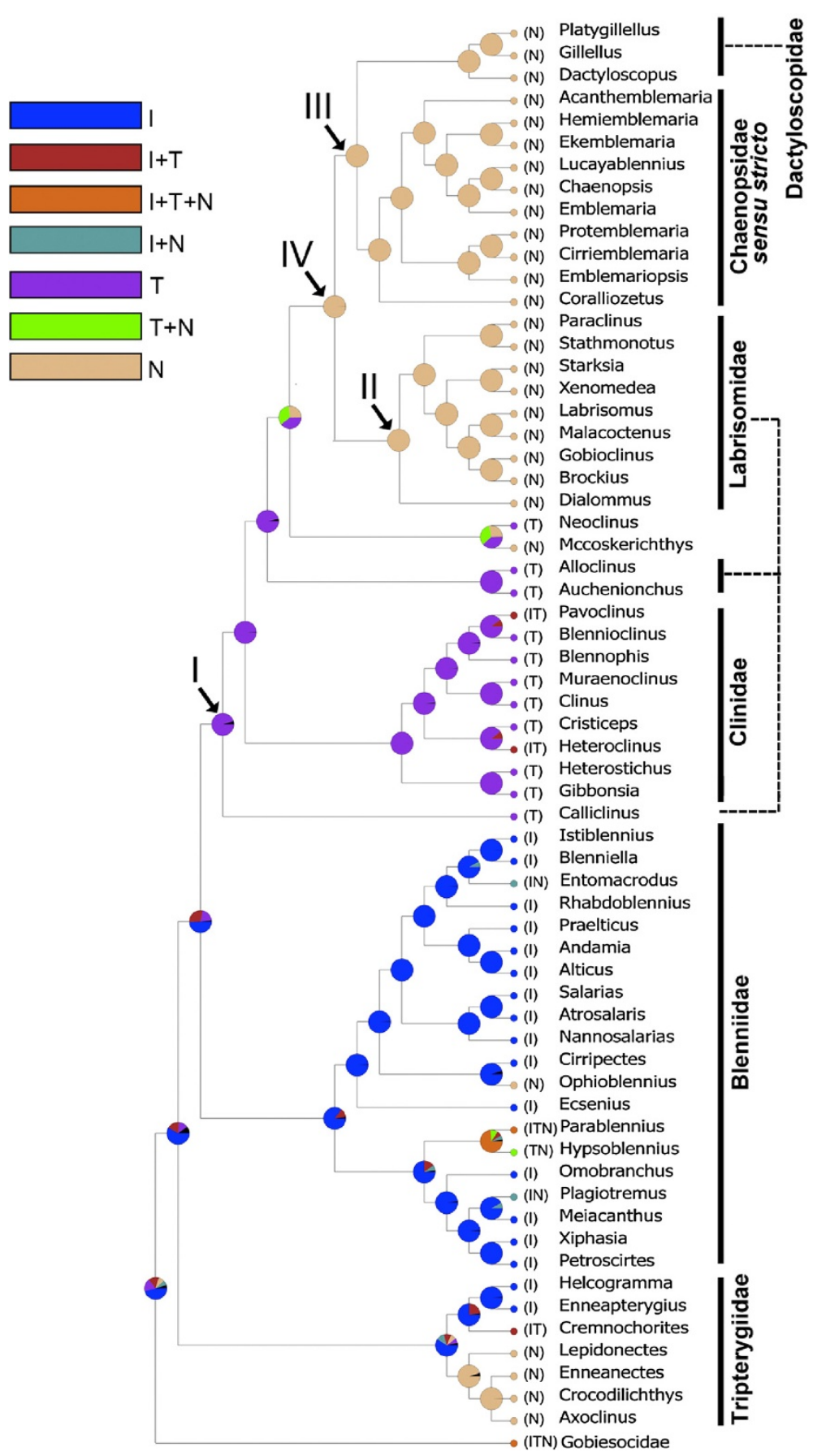

Figure 5 Inferred ancestral distribution at each node of the blenniiform phylogeny estimated by BBM analysis implemented in RASP. Pie charts at each node indicate probabilities of alternative ancestral distributions. I: tropical IndoPacific, T: temperate, N: Neotropics.

musculature. Our analysis also supports the hypothesis of Springer and Orrell [19] based on several features of the dorsal gill-arches and associated muscles that the Blenniidae is the sister group of the remaining four families of blennies (Figure 1). That clade includes the Clinidae, Labrisomidae, Chaenopsidae and Dactyloscopidae and is referred herein as the "clinioids" (node I;
Figures 1 and 4). Relationships within the clinioids are complicated and not entirely consistent with the current nomenclature, as reported by earlier studies based on morphological characters [19], allozyme data [22], and mitochondrial $12 \mathrm{~S}$ rRNA sequence data [9]. In our analysis, a single species of the labrisomid tribe Cryptotremini (Calliclinus geniguttatus) is the sister group of all other 
clinioids, and the monophyletic family Clinidae is the sister group of the remaining clinioids (Figure 4). Our analysis provided partial resolution of deep relationships within the latter lineage, but with short branch lengths to their most recent common ancestors (Figure 4), implying frequent divergence events (Additional file 2: Figure S1) consistent with a rapid radiation [38]. Bayesian Inference and Maximum Likelihood analyses support another two cryptotremins (Alloclinus holderi + Auchenionchus microcirrhis) as the sister group of the remaining species, and two "chaenopsids" (Neoclinus blanchardi + Mccoske richthys sandae) as the sister group of all others (unresolved in ML) (Figure 4). These low diversity branches are followed by two speciose lineages (node IV), one that includes most labrisomid species (node II; Figure 4), and a second, newly identified clade that includes the Chaenopsidae sensu stricto and the Dactyloscopidae (node III; Figure 4).

\section{Tripterygiidae}

The Tripterygiidae, comprising 32 genera and 164 species, can be readily distinguished from other blenniiforms by their three-part dorsal fin which lacks the "last" dorsal-fin spine $[11,24]$. Two subfamilies and eight tribes of triplefins have recently been proposed based on morphological evidence $[24,39]$, but their relationships remain unclear. Recent molecular studies on the phylogenetic relationships of triplefins are restricted to regional studies with limited taxon sampling (e.g. [40-42]) and the same is partially true of our study. We included representatives of four tribes, eight genera and 19 species from the subfamily Tripterygiinae (Table 1 and Additional file 1: Table S1) with an emphasis on eastern Pacific species. Although the monophyly of triplefins is strongly supported by our data, there is a general pattern of low node support values within the family (Figure 2). Our poor resolution of relationships within the Tripterygiidae is likely a consequence of inadequate taxon sampling (19 of 164 species), incomplete data sampling (i.e. missing data for some markers), the presence of numerous insertions and deletions observed in the sequences of TMO-4C4 and RAG1 which complicates phylogenetic analyses [43], and the possible rapid diversification of the group [40]. Clearly much broader taxon sampling and further study will be needed to resolve relationships within the triplefins.

\section{Blenniidae}

The Blenniidae, comprising 57 genera and 387 species, is the largest and most well-studied lineage of blennies [23]. Combtooth blennies share several unique features including incisiform teeth in a single comblike row on the dentaries and premaxillaries $[11,12,44]$. While the family is easily distinguished from other blennies, the classification within the Blenniidae has a long and complicated history [23]. The currently recognized tribes Parablenniini and Blenniini were at one time placed within a large, polyphyletic genus Blennius by Norman [45] and others. Based on the possession of strongly sutured dentaries, the type of the genus (Blennius ocellaris Linnaeus, 1758) was considered distinctive and it, along with a congener and two species of Spaniblennius, were designated as the tribe Blenniini [12,46,47]. The remaining "Blennius" species were allocated to various other genera and placed in the tribe Parablenniini [48]. The Parablenniini was hypothesized to be the sister group of the Salariini $[44,49]$, and these together have been recognized as the Salariinae (Figure 6a). The Blenniini was hypothesized to be the sister group of a clade comprising the Omobranchini, Phenablenniini, and Nemophini [47], and these four tribes as a group have been recognized as the subfamily Blenniinae (Figure 6a). The monophyly of each of the six tribes of blenniids, with the notable exception of the Parablenniini, has been confirmed based on morphological characters [23].

\section{a}

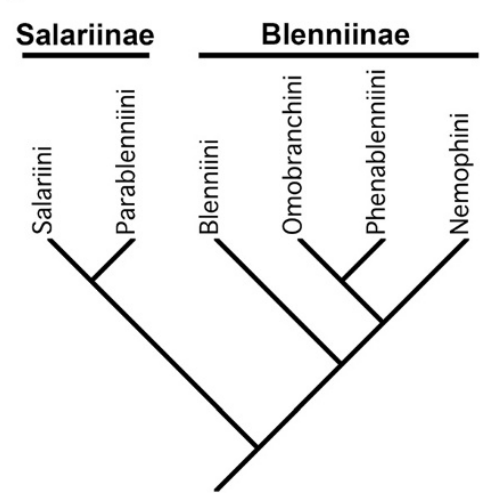

b

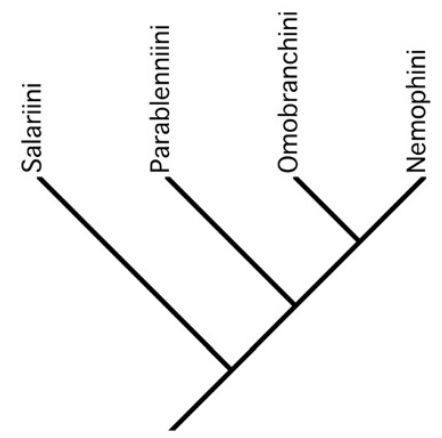

Figure 6 Phylogenetic relationships of the tribes of the Blenniidae based on (a) morphological evidence [44,47], and (b) molecular data in this study. 
We sampled 20 genera and 48 species, representing four of the six tribes and both subfamilies Blenniinae and Salariinae (Table 1 and Additional file 1: Table S1). Two low diversity tribes, the Blenniini with four species and the monotypic Phenablenniini, were not included in our analysis. The monophyly of the four tribes included in our study is supported (Figure 3), as is the monophyly of the Blenniinae. However, the monophyly of the Salariinae (sensu Bath, 2001 [49]) is not supported. Instead, we found the Parablenniini to be the sister group of the Blenniinae rather than the Salariini (Figure 6b). However, because our study included few genera of the Parablenniini (2 of 14) and did not include a member of the tribe Blenniini, additional taxon sampling is necessary to more fully resolve the relationships of the major lineages of blenniids.

The Nemophini genera Meiacanthus, Plagiotremus, Petroscirtus, and Xiphasia form a monophyletic clade that is sister to the Omobranchini genus Omobranchus (Figure 3). Within the Nemophini, this analysis provides an alternative phylogeny to the provisional hypothesis proposed by Smith-Vaniz [47] in which Meicanthus and Petroscirtes together were the sister group of Plagiotremus, Xiphasia, and Aspidontis [47]. In our analysis, Meiacan thus and Plagiotremus form a strongly supported clade that is the sister group of Petroscirtus and Xiphasia (Figure 3). Relationships of the three species of Plagio tremus included in our study are consistent with those proposed by Smith-Vaniz ([47], Fig 81).

The Salariini is the largest blenniid tribe with well over 200 species and is characterized by unique features of the premaxilla, pharyngeal arches and pectoral girdle [23]. Within the Salariini, Williams [44] recognized two lineages, the Salarias group and the Rhabdoblennius group, the former with a highly modified dentary and numerous premaxillary teeth [49], and the latter lacking known synapomorphies. In the present study, we sampled thirteen of the 28 Salariini genera. All genera with more than one included species were found to be monophyletic except Andamia and Salarias (Figure 3). However, the lineages hypothesized by Williams [44] were not supported as the only genus of the Rhabdoblennius group available for our study (Rhabdoblennius) was nested within the Salarias group (Figure 3). Otherwise, the generic relationships recovered (Figure $7 \mathrm{~b}$ ) are similar to, and better resolved, than morphologically-based hypotheses [50,51] (Figure 7a). Analyses of both character types (Figure 7a and $7 \mathrm{~b}$ ) support the genus Ecsenius as the sister group of the remaining salariins (node A), Cirripectes and Ophioblennius as sister groups (node B), Atrosalarias and Salarias as sister groups (node C), Blenniella and Istiblennius as sister groups (node D), and Praealticus as the sister group (node E) of a clade including Andamia and Alticus (node F). In the morphology-based tree (Figure 7a), the Praealticus clade shares a most recent common ancestor with Blenniella and Istiblennius, that is the sister group of the genus Entomacrodus (node G). However, the molecular analysis includes Entomacrodus, as well as Rhabdoblennius, in this clade (node G'). Finally in the morphological hypothesis, Cirripectes and Ophio blennius (node B) are the sister group of node G, while in the molecular hypothesis, the Salarias clade (node C + Nannosalarias) is the sister group of node G'.

Only two out of the fourteen Parablenniini genera (Hypsoblennius and Parablennius) are included in our study and these form a monophyletic group (Figure 3). The six Hypsoblennius species show incongruent relationships from those suggested by Bath [52] in several respects.

\section{Clinidae}

The monophyly of the Clinidae, comprising 26 genera and 85 species, is supported by the presence of cycloid scales with radii in all fields and a cordlike ligament extending from the ceratohyal to the dentary $[11,14,53]$. Three tribes are recognized within this family $[14,53]$ and a hypothesized relationship of the Myxodini as the sister group of the Clinini + Ophiclinini is based on the latter two sharing the reproductive pattern of internal fertilization with males possessing an intromittent organ [53]. Our study includes representatives of the Clinini and Myxodini and the monophyly of each is well supported (Figure 4). Species relationships within the Myxodini genus Gibbonsia (Figure 4) are congruent with the previously hypothesized relationships based on 40 allozyme loci [54], but conflict with a more recent study with expanded taxon sampling based on the same allozyme loci [22] and 12S rRNA data [9]. Within the Clinini, the Australian genera Heteroclinus and Cristiceps form a well-supported sister group to the South African genera Clinus, Muraen oclinus, Blennophis, and Pavoclinus (Figure 4).

\section{Labrisomidae}

The monophyly of the Labrisomidae has long been questioned because of the lack of any supporting morphological characters $[11,19]$ or molecular evidence $[9,22]$. Also, relationships among the five included tribes remain unclear [1]. Our study includes representatives of all five hypothesized tribes and 10 of the 14 genera (Table 1 and Additional file 1: Table $\mathrm{S} 1$ ). The only genera not included are the Eastern Pacific deepwater (> $20 \mathrm{~m}$ depth) genus Cryptotrema with two species (Cryptotremini; [14,55]), the recently described monotypic Cottoclinus (Mnierpini; [56]), and two rare and poorly known genera of uncertain relationships, Nemaclinus with one species [57] and Hap toclinus with two species $[21,58]$. The present study thus provides the most thorough investigation to date of the phylogenetic relationships of members of this family. 

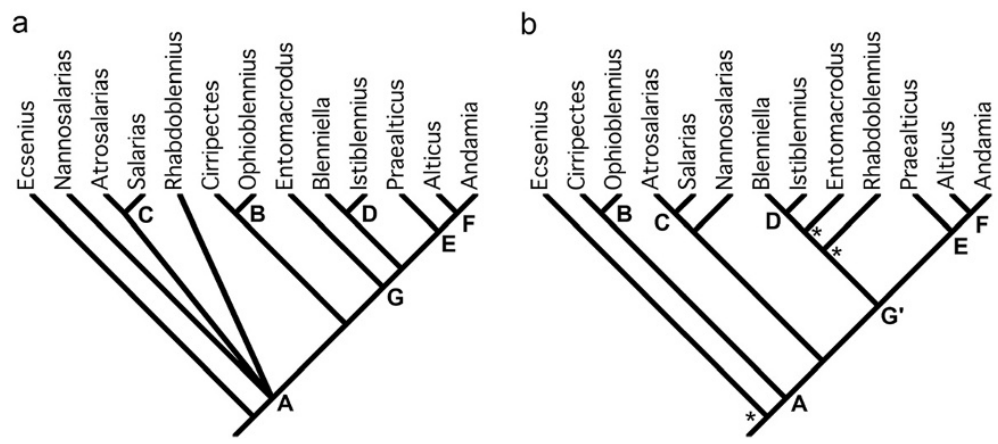

Figure 7 Generic relationships of the blenniid tribe Salariini. (a) Hypothesized relationships based on Smith-Vaniz and Springer [50] and updated in Springer and Williams [51]. (b) Consensus relationships based on Maximum Likelihood, Maximum Parsimony, and Bayesian Inference in this study. ${ }^{*}=$ node not supported by Maximum Parsimony. Nodes labeled with the same letters (A-G) in both (a) and (b) are identical. Node $\mathrm{G}^{\prime}$ in (b) is different from node $\mathrm{G}$ in (a) by including Rhabdoblennius.

In our analysis, a monophyletic Labrisomidae (node II; Figure 4) is recovered with the exclusion of the Cryptotremini and the inclusion of Stathmonotus. In our BI analysis, Stathmonotus is the sister group of the Paraclinini, and that clade is the sister group of a clade including the Starksiini and Labrisomini (Figure 4). However, relationships among the major lineages of labrisomids have strong nodal support only from the BI analysis.

The tribe Cryptotremini is the only exclusively temperate group historically allocated to the Labrisomidae while all others are primarily tropical. This tribe was first described by Hubbs [14] who included the northeastern Pacific genera Alloclinus and Cryptotrema. The Cryptotremini was later expanded with the addition of two southeastern Pacific genera (Auchenionchus and Calliclinus), although their inclusion was based on the plesiomorphic condition of branched caudal-fin rays [59]. The caudal-fin rays are unbranched in all other labrisomids but branched in the Tripterygiidae, most Blenniidae and some Dactyloscopidae. None of the analytical methods used in our study support the monophyly of the Cryptotremini (Figure 4). Instead the genus Calliclinus is the sister group of all other clinioids, the northern genus Alloclinus is grouped with the southern genus Auchenionchus, and that clade is the sister group of the clinioids exclusive of the Clinidae and Calliclinus. While support values for many of these relationships are not strong, the evolutionary position of cryptotremins as early branching lineages of a diverse clade including the labrisomids was also suggested by morphological [59] and allozyme data [22]. Additional study of cryptotremin blennies should provide a clearer picture of clinioid relationships.

The tribe Labrisomini, including Labrisomus and $M a$ lacoctenus, is not defined by morphological synapomorphies [60]. However, the monophyly of this tribe was supported by mitochondrial $12 \mathrm{~S}$ rRNA data from two Labrisomus and two Malacoctenus species [9]. With a much broader taxon sampling and multiple genetic markers in our study, the Labrisomini is recovered as monophyletic (Figure 4), but the monophyly of the genus Labrisomus as currently construed is not supported. Based on our concatenated molecular data, the seven Labri somus species are divided into two lineages (Figure 4). The first lineage, represented in our study by L. nuchipinnis and $L$. xanti (both previously allocated to the subgenus Labrisomus; Table 3; $[14,60,61]$ ) is the sister group of the genus Malacoctenus. The second Labrisomus lineage includes two sub-lineages for which generic names are available. One includes L. nigricinctus and L. striatus, species assigned to the subgenus Brockius (Table 3; [60,61]), while the other includes L. haitiensis, L. buc ciferus and L. guppyi, species previously assigned to the subgenus Gobioclinus (Table 3; [60]). Members of the subgenus Gobioclinus can be distinguished from other Labrisomus species by the presence of palatine teeth, several of which are considerably larger than those on vomer. Members of the subgenus Brockius have fewer scales in the lateral line compared to other species currently allocated to Labrisomus, and all posterior lateral-line scales have the anterior pore of the canal exposed [60]. Although the present study includes only seven of the twenty-one Labrisomus species, these three Labrisomus clades based on molecular data are congruent with Hubbs' [14] and Springer's [60] three subgenera. As Springer ([60]; p. 422) suspected, "I feel certain that some systematists would relegate each of the above subgenera (Labrisomus, Brockius, and Gobioclinus) to the rank of genus, as the differences separating them are trenchant." Our study includes the type species of all three subgenera and confirms Springer's assessment. Thus we recognize these three as full genera with the genus Brockius Hubbs, 1953 (type species = Brockius striatus Hubbs, 1953; [61]) the sister group of the genus Gobioclinus Gill, 1860 (type species = Clinus gobio Valenciennes, 1836; [62]) and the restricted genus Labrisomus (type species $=$ Clinus pectinifer Valenciennes, 1836, a synonym of Clinus 
Table 3 Species allocated to three genera previously placed in the genus Labrisomus

\begin{tabular}{|c|c|}
\hline \multirow[t]{11}{*}{$\begin{array}{l}\text { Labrisomus } \\
\text { Swainson, } 1837\end{array}$} & $\begin{array}{l}\text { Labrisomus conditus Sazima, Carvalho-Filho, Gasparini } \\
\text { and Sazima, } 2009^{a}\end{array}$ \\
\hline & Labrisomus cricota Sazima, Gasparini and Moura, $2002^{a}$ \\
\hline & Labrisomus fernandezianus (Guichenot, 1848)" \\
\hline & Labrisomus jenkinsi (Heller and Snodgrass, 1903) \\
\hline & Labrisomus multiporosus Hubbs, 1953 \\
\hline & Labrisomus nuchipinnis (Quoy and Gaimard 1824)* \\
\hline & Labrisomus philippii (Steindachner, 1866) \\
\hline & Labrisomus pomaspilus Springer and Rosenblatt, $1965^{\text {a }}$ \\
\hline & Labrisomus socorroensis Hubbs, 1953 \\
\hline & Labrisomus wigginsi Hubbs, 1953 \\
\hline & Labrisomus xanti Gill, $1860^{+}$ \\
\hline
\end{tabular}

$\begin{array}{ll}\text { Brockius } & \text { Brockius albigenys (Beebe and Tee-Van, 1928) } \\ \text { Hubbs, 1953 } & \text { Brockius nigricinctus (Howell Rivero, 1936) }{ }^{+} \\ & \text {Brockius striatus (Hubbs, 1953)*+ }\end{array}$

Gobioclinus Gobioclinus bucciferus (Poey, 1868) ${ }^{+}$

Gill, 1860 Gobioclinus dendriticus (Reid, 1935)

Gobioclinus filamentosus (Springer, 1960)

Gobioclinus gobio (Valenciennes 1836)*

Gobioclinus guppyi (Norman, 1922) ${ }^{+}$

Gobioclinus haitiensis (Beebe and Tee-Van, 1928) ${ }^{+}$

Gobioclinus kalisherae (Jordan, 1904)

${ }^{\mathrm{a}}=$ placement based on details in the original species description;

${ }^{*}=$ type species; ${ }^{\#}=$ placement tentative; ${ }^{+}=$included in this study.

nuchipinnis Quoy and Gaimard, 1824) the sister group of the genus Malacoctenus. Species placed in each of these genera based on morphological criteria are listed in Table 3.

Ten of the twenty-one Malacoctenus species are included in our study and these form a well-supported clade that is the sister group of Labrisomus sensu stricto (Figure 4). Our study recovered one well-supported lineage within Malacoctenus comprising five Eastern Pacific species. However, greater taxon sampling, especially of Caribbean species, is needed to resolve the relationships within this speciose genus.

The monophyly of the tribe Starksiini, including Starksia and Xenomedea, is supported in our analysis (Figure 4). Members of this lineage reportedly share internal fertilization and a modification of the first anal-fin spine that functions as an intromittent organ in males [14,63]. However, a recent study indicates that reproductive modes vary within this lineage and not all Starksia species exhibit internal fertilization [64].
The two genera currently included in the tribe Paraclinini, Paraclinus and Exerpes, share the unique characters of a spine on the posterior margin of the opercle and $0-2$ segmented dorsal-fin rays $[14,65,66]$. Results from our study support the monophyly of the tribe (Figure 4), although the monotypic genus Exerpes is nested within Paraclinus, rendering the genus Paraclinus paraphyletic. Exerpes asper can be distinguished from members of the genus Paraclinus in having greatly prolonged snout, no cirri on the nape or eye, scales in the anterior segment of the lateral line consisting of a pore at each end of a tube, and by the absence of the suborbital lateral-line canal [14]. However, this species shares several features such as an elongate snout with selected Paraclinus species, especially Paraclinus infrons [66]. Additional study of relationships within this lineage are needed, but based on our findings and those of Brooks [66], we synonomize the genus Exerpes Jordan and Evermann, 1896 with Paraclinus Mocquard, 1888.

The phylogenetic relationships of the seven species of small (<55 mm SL), cryptic, eel-like blennioids of the genus Stathmonotus have been controversial for many years [37]. Jordan [15] considered Stathmonotus to be closely related to chaenopsids based on both groups lacking scales. However, Springer [67] included the scaled species Auchenistius stahli in Stathmonotus, and suggested that their affinities were with Paraclinus, not chaenopsids. Consequently, Stathmonotus was included in the generalized blenniiform family Labrisomidae $[68,69]$. Based on six morphological synapomorphies, Hastings and Springer [37] placed Stathmonotus back in the Chaenopsidae as the sister group of the Chaenopsinae (= Chaenopsidae of Stephens, 1963; [70]). The present study based on molecular data confirms the distinctiveness of Stathmonotus, but the BI analysis supports its relationship as the sister group of the Paraclinini (Figure 4). Stathmonotus is similar to Paraclinus in post-cranial morphology, especially in having the dorsal fin comprised entirely (or mostly in the case of some Paraclinus species) of robust spines. However, it is similar to chaenopsids in cranial morphology and parsimony analysis of morphological characters places Stathmonotus with the chaenopsids because more characters are evident within the cranial region [37]. These observations, with different suites of characters shared with disparate lineages, are consistent with a hybrid origin for this enigmatic taxon [71], but this hypothesis remains speculative, requiring further study. Given its morphological distinctiveness [37], we recommend recognizing the tribe Stathmonotini within the Labrisomidae.

\section{Neocliniini}

Stephens [70] hypothesized the close relationship of the temperate hole-dwelling genus Neoclinus with the tropical 
chaenopsid blennies. This relationship was given further credence by the discovery of the tropical species Mccoskerichthys sandae that resembles Neoclinus, but also shares several morphological features (e.g., medially fused nasal bones) with chaenopsids [72]. The recent placement of Neoclinus and Mccoskerichthys in the lineage with the chaenopsids based on a parsimony analysis of morphological features [37] is not supported in our study and implies significant morphological convergence associated with the hole-dwelling lifestyles of these fishes. The sistergroup relationship between Neoclinus and Mccoskerichthys is well supported in our study, thus we recommend their designation as the Neocliniini. However, their placement as the sister group of the clinioids exclusive of the Cryptotremini and Clinidae (Figure 4) is only weakly supported by Bayesian Inference. Further study is required to determine their position within the Blenniiformes.

\section{Chaenopsidae}

In our analysis, the Chaenopsidae is monophyletic with the exclusion of Stathmonotus, Neoclinus and Mccoskerichthys, three genera allocated to this group by Hastings and Springer [37]. This result resurrects the definition of the Chaenopsidae sensu Stephens [70,73]. This clade is well-supported by morphological features and relationships within it were recently analyzed by Lin and Hastings [74] using a combination of molecular and morphological characters. Results from the present analysis that included a much broader selection of outgroup taxa but fewer ingroup species, are largely congruent with those of Lin and Hastings [74] except for species relationships within Acanthemblemaria, a group recently studied in greater detail [75].

\section{Dactyloscopidae}

The dactyloscopids, also known as sand stargazers, are a distinctive group with several known morphological syanpomorphies, many of which are associated with their sand or gravel dwelling behaviors $[1,11,36]$. In our study, only four out of the 48 dactyloscopid species were included and they formed a well-supported monophyletic group based on our molecular data (Figure 4).

\section{Unresolved issues in blenniiform relationships}

While our analysis clarifies several aspects of the relationships of the Blenniiformes, several significant questions remain. Relationships within the Tripterygiidae are not well understood and our study, with limited taxon sampling, contributes little to this issue. Inclusion of taxa from the southern Pacific Ocean, especially from New Zealand and southern Australia where this group is especially diverse [24,39-42], is needed to resolve relationships within the triplefins. Within the Blenniidae, the relationships of the low diversity, but morphologically distinctive, tribes
Blenniini and Phenablenniini need further study. Also, the monophyly of the Parablenniini has not been confirmed although its reality and its relationships to other blenniids may have significant bearing on relationships within the combtooth blennies [23]. Several significant questions remain regarding relationships among the lineages here termed the clinioids (node I; Figures 1 and 4). Chief among these is the relationships of the species currently allocated to the Cryptotremini. This low diversity group of relatively generalized blennies is apparently not monophyletic and in our analysis, its members are variously placed as the sister group of speciose clades of blennies. Morphological convergence in lifestyle and associated morphological features appear to have confounded past morphologically-based analyses of blenny relationships, especially among the tube-dwelling lineages. Also, relationships of the enigmatic worm blennies, genus Stathmonotus, remain unclear as they have for decades. This study supports other recent studies [32,37] in hypothesizing a sister-group relationship of the Dactyloscopidae and Chaenopsidae (node III; Figure 4). Preliminary study indicates possible morphological features uniting these two (PAH, personal observations), but characterization of this clade may have been confounded by the inclusion of the apparently unrelated fishes of the genera Neoclinus, Mccoske richthys and Stathmonotus within the Chaenopsidae. Finally, our understanding of species level-relationships within most lineages included herein suffers from poor taxon sampling. Thus relationships recovered in our analyses within speciose genera for which we had few representative species should be considered tentative.

Because of these and other significant issues, we are reluctant to recommend major changes to the higher-level nomenclature of the Blenniiformes at this time. While progress has been made, these and other remaining challenges in resolving blenniiform relationships will require incorporation of additional molecular markers for these and additional taxa, and importantly inclusion of morphological features in a total evidence analysis.

\section{Biogeography of the Blenniiformes}

Our mean estimated divergence time for the Blenniiformes, 60.3 mya (Additional file 2: Figure S1), is similar to recent estimates from other studies of ray-finned fishes that place the origin of the Blenniiformes at around 60 [76] to 68 mya [35]. Our study also implies the origin of a largely Neotropical clade of over 240 species (node IV) of the Labrisomidae, Chaenopsidae and Dactyloscopidae at approximately 37.6 mya, somewhat more recent than other estimates of 40 mya [35] and 48 mya [34] for the same clade.

The majority of species in the families Blenniidae and Tripterygiidae occur in the tropical IndoPacific with various other lineages of these families found in the 
Neotropics and temperate waters of the world $[6,77,78]$. Our analysis implies an origin of the Blenniiformes in the present-day IndoPacific region (Figure 5, Additional file 3: Figure S2), consequently in the Tethys Sea at approximately 60 mya. The origin of the largely Neotropical clade including the Labrisomidae, Chaenopsidae and Dactyloscopidae (node IV) at approximately 37.6 mya is coincident with the increasing opening of the Atlantic Ocean and separation of the New World and Old World land masses, but well before the closing of the Tethys Sea corridor at 12-18 mya [79,80]. This result supports the findings of Bellwood and Wainwright [81] that the east and west Tethyan reef-fish faunas had diverged well before the terminal Tethyan event.

Interestingly, the intervening blenniiform clades between the primarily east and west Tethyan groups are almost exclusively temperate in distribution (Figure 5, Additional file 3: Figure S2). This finding implies either an evolutionary pathway across temperate coastal areas between increasingly separate east and west tropical regions of the Tethys Sea, or more likely, the subsequent restriction of the intervening clades to temperate refugia [82]. These groups include low-diversity lineages currently included in the paraphyletic Cryptotremini (e.g., Calliclinus, Auchenionchus, Alloclinus and Cryptotrema) [59] and the genus Neoclinus [6,61], as well as the relatively speciose Clinidae, with 85 species, that has undergone significant diversification within distant temperate regions of the world [78]. The occurrence of these related clades in both northern and southern temperate regions indicates that they have successfully crossed intervening tropical regions during their evolutionary history $[82,83]$. Better resolution of relationships and timing of divergence of these largely temperate lineages $[6,77,78]$ is an important key to reconstructing the biogeographic history of the Blenniiformes in greater detail.

Other Neotropical lineages of blenniiforms include the salariin blenniid genera Ophioblennius and Scartichthys (the latter not included in our study), part or parts of the Parablenniini $[48,84]$, and one or more lineages within the Tripterygiidae [6,24], as well as the Gobiesocini within the sistergroup of blenniiforms, the Gobiesocidae [85]. A more fully resolved phylogeny of these groups with increased taxon sampling is needed to determine which, if any, of these lineages may have diverged coincident with the Neotropical blenniiforms (node IV). A few species of blennies from other primarily IndoPacific clades have invaded the Neotropics including species of the salariin genus Entomacrodus [86] and a single species of the nemophin blenniid genus Plagiotremus [47]. These species are well-nested within IndoPacific clades (Figure 5), supporting the hypotheses that they dispersed to the Neotropics after the origin of their respective genera in the IndoPacific region [6]. Similarly, the few species of primarily Neotropical clades occuring in the eastern Atlantic (e.g., species of the labrisomid genera Labrisomus and Malacoctenus; [6,87]), and members of the temperate genus Neoclinus in the northwestern Pacific [88], likely represent relatively recent dispersal events from their regions of origin.

\section{Conclusions}

In this study we reconstruct the phylogeny of the Blenniiformes with significantly broader taxon sampling (150 blenniiform species), substantially more genetic information (one mitochondrial and four nuclear markers), and more strategic outgroup representation (Gobiesocidae, Opistognathidae, and Grammatidae) than in previous studies. Progress has been made in resolving the blenniiform evolutionary relationships especially at the inter-familial level and within the Labrisomidae. Several nomenclatural changes are proposed especially in the "clinioid" clade. Examination of global distributions of blenny genera included in our analysis and estimation of divergence times imply an origin of the Blenniiformes in the present-day IndoPacific region, consequently in the Tethys Sea around 60 million years ago. A large and diverse Neotropical clade (node IV, Figures 1, 4, and 5) arose around 37.6 million years ago with intervening lineages largely restricted to temperate regions.

\section{Methods}

\section{Taxon sampling}

Molecular data for 158 terminal taxa were collected. Additional file 1: Table S1 details the included species, collection localities and deposition of voucher specimens. Our taxon sampling included representatives of all six blenniiform families (Table 1): Tripterygiidae (18 species), Blenniidae (48), Labrisomidae (36), Chaenopsidae (30), Clinidae (14), and Dactyloscopidae (4), as well as the outgroups Gobiesocidae (6), Opistognathidae (1), and Grammatidae (1). Currently recognized lineages within the blenniiform families were sampled with representative species where available (Table 1). Tissue samples were from the Marine Vertebrate Collection at Scripps Institution of Oceanography (SIO), the University of Kansas Natural History Museum (KU), the Biodiversity Research Museum at Academia Sinica (ASIZP), Taiwan and the Australian Museum (AM).

\section{DNA extraction, amplification and sequencing}

Total genomic DNA was extracted from muscle tissue with a Qiagen (Chatsworth, CA) QIAquick Tissue Kit following the manufacturer's instructions. DNA sequences of one mitochondrial DNA marker, Cytochrome C Oxidase I (COI), and four nuclear markers, TMO-4C4, RAG1, Rhodopsin and Histone H3, were obtained. In addition to the primers used in a recent publication on chaenopsid 
phylogeny [74], six new primers were designed for amplifying PCR products across this broad sample of taxa: two extended inside primers from TMO-F3 and TMO-R3 for TMO-4C4, TMO-F4 5'-GGTGAAGTGGTTCTGCAAC A-3' and TMO-R4 5'-GCYGTGTACTCNGGRATRGT3'; two gobiesocid-specific inside primers for RAG1, Rag-GoF 5'-TTCCTCGATCATTTAGTTTCCA-3' and Rag-GoR 5'-GAAGGGCTTGGAGGAAACTC-3'; two blenniiform-specific inside primers for Rhodopsin, RhodBleF 5' -CGTCACCCTCGAACACAAGAA-3' and RhodBleR 5'-GTTGTAGATGGAGGAACTCTT-3'. The PCR was performed on a Mastercycler EP Gradient $S$ (Eppendorf, Hamburg, Germany) with the following conditions: $94^{\circ} \mathrm{C}$ for one minute for initial denaturing, 35 cycles of $94^{\circ} \mathrm{C}$ for $30 \mathrm{sec}, 52-56^{\circ} \mathrm{C}$ for 45 seconds, and $72^{\circ} \mathrm{C}$ for $45 \mathrm{sec}$, followed by $72^{\circ} \mathrm{C}$ for 5 minutes as the final extension. Resulting amplicons were purified with Exonuclease I

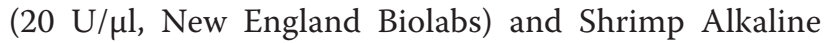
Phosphatase (1 U/ $\mu$ l, Roche) in order to remove singlestranded DNA and unincorporated dNTPs. Sequencing was done in both directions with the amplification primers and DYEnamicTM ET dye terminator sequencing kit on an automated MegaBACE 500 DNA sequencer (Amersham Biosciences Corp., Piscataway, NJ).

\section{DNA sequence alignment, partition, and analysis}

Sequences were assembled, edited, and aligned with no gaps interrupting reading frames based on translated protein sequences in Geneious [89]. Nucleotide sequences were checked on the NCBI database (http://www.ncbi. nlm.nih.gov/) for possible stop codons as an indication of pseudogenes. Because all five genetic markers are proteincoding genes, the rapidly evolving third codon positions were partitioned from the slower evolving first and second positions in Bayesian and likelihood analyses, resulting in ten total partitions [90]. To avoid base frequency deviations across taxa which can potentially mislead phylogenetic reconstruction [91], the chi-square test of base frequency homogeneity across taxa was executed for each partition using PAUP 4.0b10 [92]. The Akaike Information Criterion (AIC) [93] implemented in jModelTest v0.1.1 [94,95] was used to select the best-fit evolutionary model for each partition (Table 2). Likelihood calculations were carried out for 88 models, including 11 substitution schemes, equal or unequal base frequencies, a proportion of invariant sites (I), and rate variation among sites with four rate categories $(G)$ on a BIONJ-JC fixed tree.

\section{Phylogenetic analysis}

Maximum likelihood (ML), Bayesian inference (BI), and maximum parsimony (MP) analyses were conducted to reconstruct the phylogenetic relationships. Maximum likelihood tree searching was conducted in Garli 2.0 [96] under the CIPRES Science Portal v2.2 [97]. Best-fit evolutionary models selected by jModeltest were applied to the ten genetic partitions (five genes for first + second and third codon positions) (Table 2). If a selected model could not be implemented in Garli, the least complex model that included all of the parameters of the selected model was used instead. Therefore, the General Time Reversible model with gamma rate heterogeneity model $(G T R+G)$ was selected for the third codon position of $\mathrm{COI}$, and the GTR $+\mathrm{I}+\mathrm{G}$ model [98] was selected for all other partitions. Twelve replicates were run to find the tree topology with the best likelihood. The setting of 1,000 replicate bootstrap analysis was identical to the above, except the number of generations without topology improvement required for termination (genthreshfortopoterm) was reduced from 20,000 (default) to 10,000 to reduce the running time as suggested in the manual [96].

Bayesian Metropolis coupled Markov chain Monte Carlo (MCMC) estimation of the phylogeny was carried out using MrBayes v3.1.2 [99] under the CIPRES Science Portal. The dataset was partitioned and assigned evolutionary models as in the ML analyses. A partitioned mixed-model analysis was applied and all model parameter values were "unlinked" among partitions [100]. In all analyses, the average substitution rates (prset ratepr = variable) and model parameters including the branch lengths within the tree (unlink brlens) were allowed to vary among partitions. Two simulated independent runs were performed for 10 million generations each and starting from different random trees. Each run comprised four chains (one cold and three heated) and was sampled every 1,000 generations. The sampled parameter values from Bayesian MCMC were evaluated in Tracer v1.4 (http://beast.bio.ed.ac.uk/Tracer) and the generations before reaching a plateau were discarded as burnin. Trees from the stationary phase of the two runs were then pooled by LogCombiner v1.5.4 [101] and the $50 \%$ majority tree was exported by Mesquite v2.73 [102]. Assigning this tree as the target tree, the posterior probability of each node and the mean branch lengths were calculated with TreeAnnotator v1.5.4 [101].

Maximum parsimony analyses were conducted using PAUP 4.0b10. Heuristic searches were performed using tree bisection reconnection (TBR) with branch-swapping from 1,000 random-addition-sequence replicates to avoid entrapment in local optima. All nucleotide sites were equally weighted and gaps were treated as missing characters. Nonparametric node supports for trees were estimated with 1,000 heuristic searches $(\operatorname{maxTree}=500)$ starting with 10 random addition sequence replicates.

\section{Molecular dating}

Divergence times of the blenniiform lineages sampled in our study were estimated with a relaxed molecular clock 
analysis [103]. Relative divergence times of nodes were estimated in BEAST v1.7.2 assuming an uncorrelated lognormal model (UCLN) of rate variation among branches in the tree and a Yule-process-speciation prior of the branching rate $[101,103]$. As in the maximum likelihood and Bayesian analysis described before, the same ten data partitions and molecular evolutionary models were applied to estimate the posterior density of relative divergence times. With TreeEdit v1.0a10 (http://tree.bio.ed.ac.uk/software/treeedit/), the best ML tree from Garli was converted to an ultrametric tree assuming the origin of the Blenniidae as 41 million years old as estimated from a bony fish phylogeny including 21 molecular markers and 1410 fish taxa [34] and assigned as the starting tree. We did not incorporate the putative blenniid fossil from the Monte Bolca formation (50 mya; [104]), because its identity as a blenniid is in doubt $([11,105]$, Springer, pers. comm). Three independent MCMC analyses were each run for 40 million generations, sampled every 1000 generations, and discarding the first $10 \%$ of samples, resulting in acceptable mixing as determined by Tracer. These three runs were combined to obtain an estimate of the posterior distribution. The posterior probability density of the combined tree and log files was summarized on a maximum clade credibility tree with TreeAnnotator.

\section{Biogeographic analysis}

The general distributions of blenniiform genera with representatives included in our analysis were scored as either tropical IndoPacific (I), Neotropical (N), or temperate ( $\mathrm{T}$; Additional file 4: Table S2). Genera with species present in more than one of these were scored as polymorphic except where phylogenetic evidence implies recent dispersal into another region after the origin of the genus. For example, Plagiotremus (Blenniidae) was scored as IndoPacific because the single Neotropical species $(P$. azaleus) is nested within an otherwise entirely IndoPacific clade ([6,47]; Figure 3).

We used both parsimony implemented in Mesquite and Bayesian Binary MCMC (BBM) methods implemented in Reconstruct Ancestral States in Phylogenetics v2.1 beta (RASP; [106]) to reconstruct geographical areas at nodes in the phylogeny. The genus-level topology of the best ML tree was used for the reconstruction. The BBM analysis was conducted with estimated character state frequencies (F81) and gamma-distributed rate variation between sites. The root distribution was set to null (i.e. the outgroup is assigned to a new area where none of the ingroup taxa occur). Two independent runs of 10 chains with a temperature of 0.1 were run for one million generations, sampled every 100 generations, and the first 2,500 samples were discarded. A distance between runs of less than 0.01 was used as an indication of convergence.

\section{Additional files}

Additional file 1: Table S1. Abbreviations, voucher numbers, localities, sample IDs, and Genbank accession numbers for 158 terminal taxa used in this phylogenetic analysis.

Additional file 2: Figure S1. Posterior maximum clade credibility relative time tree of blenniiform species inferred from a relaxed molecular clock analysis using BEAST. Branches are scaled to age estimates. Bars at nodes reflect the $95 \%$ highest posterior density of the age estimates.

Additional file 3: Figure S2. Ancestral distribution at each node of the blenniiform phylogeny estimated by MP analysis implemented in Mesquite.

Additional file 4: Table S2. Biogeographical distribution of blenniiform genera.

\section{Competing interests}

The authors declare that they have no competing interests.

\section{Authors' contributions}

$\mathrm{HCL}$ and PAH conceived the study, conducted analyses and wrote the manuscript. Both authors read and approved the final manuscript.

\section{Acknowledgements}

We thank N. Knowlton for providing laboratory space and equipment, G. Rouse for assisting with data analyses and providing critical comments, R. Burton for insightful comments on molecular methods and the sequencing machine, HJ Walker for curatorial assistance, and R. Rosenblatt and C. Wills for providing valuable comments. Tissue samples were generously provided by the Marine Vertebrate Collection at Scripps Institution of Oceanography, University of Kansas Natural History Museum, Biodiversity Research Museum at Academia Sinica, Taiwan and the Australian Museum. This work was supported by the Study-abroad Scholarship from the Ministry of Education, Taiwan, SIO Rosenblatt Fellowship, the E. B. Scripps Foundation, a gift from B. Shor, the UCSD Academic Senate and a dissertation improvement grant from UC MEXUS.

Received: 9 July 2013 Accepted: 16 September 2013

Published: 25 September 2013

\section{References}

1. Hastings PA, Springer VG: Systematics of the Blennioidei and the included families Dactyloscopidae, Chaenopsidae, Clinidae and Labrisomidae. In The Biology of Blennies. Edited by Patzner RA, Gonçalves EJ, Hastings PA, Kapoor BG. Enfield: Science Publishers; 2009:3-30.

2. Griffiths SP: Rockpool ichthyofaunas of temperate Australia: species composition, residency and biogeographic patterns. Estuar Coast Shelf Sci 2003, 58:173-186.

3. Thomson DA, Gilligan MR: Rocky-shore Fishes. In A new island biogeography of the Sea of Cortes. Edited by Case TJ, Cody ML, Ezcurra E. New York: Oxford University Press; 2002:154-180.

4. Paulin C, Roberts C: The Rockpool Fishes of New Zealand. Wellington: Museum of New Zealand Te Papa Tongarewa; 1992.

5. Patzner RA, Gonçalves EJ, Hastings PA, Kapoor BG: The Biology of Blennies. Enfield: Science Publishers; 2009.

6. Hastings PA: Biogeography of New World Blennies. In The Biology of Blennies. Edited by Patzner RA, Gonçalves EJ, Hastings PA, Kapoor BG. Enfield: Science Publishers; 2009:95-118.

7. Rosenblatt $\mathrm{RH}$ : Some aspects of speciation in marine shore fishes. Syst Assoc Publ 1963, 5:171-180.

8. Hastings PA: Biogeography of the tropical eastern Pacific: distribution and phylogeny of chaenopsid fishes. Zool J Linn Soc 2000, 128:319-335.

9. Stepien CA, Dillon AK, Brooks MJ, Chase KL, Hubers AN: The evolution of blennioid fishes based on an analysis of mitochondrial 12S rRNA. In Molecular Systematics of Fishes. Edited by Kocher TD, Stepien CA. San Diego: Academic Press; 1997:245-270.

10. Rosenblatt RH: Blennioidei: Introduction. In Ontogeny and Systematics of Fishes, Special publication 1. American Society of Ichthyologists and Herpetologists; 1984:551-552. 
11. Springer VG: Definition of the suborder Blennioidei and its included families (Pisces: Perciformes). Bull Mar Sci 1993, 52:472-495.

12. Springer VG: Osteology and classification of fishes of the family Blenniidae. U S Natl Mus Bull 1968, 284:1-85.

13. Gosline WA: The suborders of perciform fishes. Proc U S Natl Mus 1968, 124:1-78

14. Hubbs C: A contribution to the classification of the blennioid fishes of the family Clinidae, with a partial revision of eastern Pacific forms. Stanford Ichthy Bull 1952, 4:41-165.

15. Jordan DS: A classification of fishes, including families and genera as far as known. Stanford Univ Publ Biol Sci 1923, 3:77-243.

16. Regan CT: The classification of the blennioid fishes. Ann Mag Nat Hist Ser 8 1912, 36:265-280.

17. Wiley E, Johnson G: A teleost classification based on monophyletic groups. In Origin and Phylogenetic Interrelationships of Teleosts. Edited by Nelson J, Schultze H-P, Wilson M. München: Verlag Dr. Friedrich Pfeil; 2010:123-182.

18. Johnson GD: Percomorph phylogeny: A survey of acanthomorphs and a new proposal. Bull Mar Sci 1993, 52:554-626.

19. Springer VG, Orrell TM: Phylogenetic analysis of the families of acanthomorph fishes based on dorsal gill-arch muscles and skeleton. Bull Biol Soc Washington 2004, 11:237-260.

20. Mooi RD, Gill AC: Association of epaxial musculature with dorsal-fin pterygiophores in acanthomorph fishes, and its phylogenetic significance. Bull Nat Hist Mus London, Zool 1995, 62:121-137.

21. Böhlke JE, Robins $\mathrm{CH}$ : Description of a new genus and species of clinid fish from the Western Caribbean, with comments on the families of the Blennioidea. Proc Acad Nat Sci Philad 1974, 126:1-8.

22. Stepien CA, Dixon MT, Hills DM: Evolutionary relationships of the blennioid fish families Clinidae, Labrisomidae and Chaenopsidae: congruence between DNA seqeunce and allozyme data. Bull Mar Sci 1993, 52:496-515.

23. Hastings PA, Springer VG: Systematics of the Blenniidae (Combtooth Blennies). In The Biology of Blennies. Edited by Patzner RA, Gonçalves EJ, Hastings PA, Kapoor BG. Enfield: Science Publishers; 2009:69-91.

24. Fricke R: Systematics of the Tripterygiidae (triplefins). In The Biology of Blennies. Edited by Patzner RA, Gonçalves EJ, Hastings PA, Kapoor BG. Enfield: Science Publishers; 2009:31-67.

25. Chen W-J, Bonillo C, Lecointre G: Repeatability of clades as a criterion of reliability: a case study for molecular phylogeny of Acanthomorph (Teleostei) with larger number of taxa. Mol Phyl Evol 2003, 26:262-288.

26. Simmons MP, Miya M: Efficiently resolving the basal clades of a phylogenetic tree using Bayesian and parsimony approaches: a case study using mitogenomic data from 100 higher teleost fishes. Mol Phyl Evol 2004, 31:351-362.

27. Miya M, Satoa TP, Nishida M: The phylogenetic position of toadfishes (order Batrachoidiformes) in the higher ray-finned fish as inferred from partitioned Bayesian analysis of 102 whole mitochondrial genome sequences. Biol J Linn Soc 2005, 85:289-306.

28. Dettai A, Lecointre G: Further support for the clades obtained by multiple molecular phylogenies in the acanthomorph bush. C R Biol 2005, 328:674-689.

29. Setiamarga DHE, Miya M, Yamanoue Y, Mabuchi K, Satoh TP, Inoue JG, Nishida M: Interrelationships of Atherinomorpha (medakas, flyingfishes, killifishes, silversides, and their relatives): The first evidence based on whole mitogenome sequences. Mol Phyl Evol 2008, 49:598-605.

30. Li B, Dettaï A, Cruaud C, Couloux A, Desoutter-Meniger M, Lecointre G: RNF213, a new nuclear marker for acanthomorph phylogeny. Mol Phyl Evol 2009, 50:345-363.

31. Smith WL, Craig MT: Casting the percomorph net widely: The importance of broad taxonomic sampling in the search for the placement of serranid and percid fishes. Copeia 2007, 2007:35-55.

32. Wainwright PC, Smith WL, Price SA, Tang KL, Sparks JS, Ferry LA, Kuhn KL, Eytan RI, Near TJ: The evolution of pharyngognathy: A phylogenetic and functional appraisal of the pharyngeal jaw key innovation in labroid fishes and beyond. Syst Biol 2012,61:1001-1027.

33. Smith WL, Wheeler WC: Polyphyly of the mail-cheeked fishes (Teleostei: Scorpaeniformes): Evidence from mitochondrial and nuclear sequence data. Mol Phyl Evol 2004, 32:627-647.

34. Betancur-R R, Broughton R, Wiley E, Carpenter K, López J, Li C, Holcroft N, Arcila D, Sanciangco M, Cureton J, et al: The tree of life and a new classification of bony fishes. PLOS Curr Tree of Life 2013. Edition 1. Doi: 10.1371/currents.tol.53ba26640df0ccaee75bb165c8c26288

35. Near TJ, Dornburg A, Eytan Rl, Keck BP, Smith WL, Kuhn KL, Moore JA, Price SA, Burbrink FT, Friedman M, et al: Phylogeny and tempo of diversification in the superradiation of spiny-rayed fishes. Proc Natl Acad Sci 2013, 110:12738-12743.

36. Doyle KD: Phylogeny of the sand stargazers (Dactyloscopidae: Blennioidei). Copeia 1998, 1998:76-96.

37. Hastings PA, Springer VG: Review of Stathmonotus with redefinition and phylogenetic analysis of the Chaenopsidae (Teleostei:Blennioidei). Smith Contrib Zool 1994, 558:1-48.

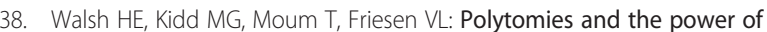
phylogenetic inference. Evolution 1999, 53:932-937.

39. Fricke R: Tripterygiid Fishes of Australia, New Zealand and the Southwest Pacific Ocean (Teleostei). Koenigstein: Koeltz Scientific Books; 1994.

40. Carreras-Carbonell J, Macpherson E, Pascual M: Rapid radiation and cryptic speciation in Mediterranean triplefin blennies (Pisces: Tripterygiidae) combining multiple genes. Mol Phyl Evol 2005, 37:751-761

41. Geertjes GJ, Kamping A, van Delden W, Videler JJ: Genetic relationships among one non-endemic and two endemic Mediterranean triplefin blennies (Pisces, Blennioidei). Mar Ecol 2001, 22:255-265.

42. Hickey AJR, Clements KD: Genome size evolution in New Zealand triplefin fishes. J Hered 2005, 96:356-362.

43. Loytynoja A, Goldman N: Phylogeny-aware gap placement prevents errors in sequence alignment and evolutionary analysis. Science 2008, 320:1632-1635.

44. Williams JT: Phylogenetic relationships and revision of the blenniid fish Scartichthys. Smith Contrib Zool 1990, 492:1-30.

45. Norman JR: Notes on the blennioid fishes. I. A provisional synopsis of the genera of the family Blenniidae. Ann Mag Nat Hist Ser 11 1943, 10:793-812.

46. Bath H: Revision der Blenniini. Senck Biol 1977, 57:167-234

47. Smith-Vaniz WF: The saber-toothed blennies, tribe Nemophini (Pisces; Blenniidae). Monogr Acad Nat Sci Philad 1976, 19:1-196.

48. Bock M, Zander CD: Osteological characters as tool for blenniid taxonomy - A generic revision of European Blenniidae (Percomorphi; Pisces). Z Zool Syst Evol 1986, 24:138-143.

49. Bath $\mathrm{H}$ : Osteology and morphology of fishes of the subfamily Salariinae and its junior synonym Parablenniinae (Pisces: Blennidae). Stutt Beitr Naturkd 2001, A268:1-42.

50. Smith-Vaniz WF, Springer VG: Synopsis of the tribe Salariini, with description of five new genera and three new species (Pisces: Blenniidae). Smith Contrib Zool 1971, 73:1-72.

51. Springer VG, Williams JT: The Indo-Pacific blenniid fish genus Istiblennius reappraised: a revision of Istiblennius, Blenniella, and Paralticus, new genus. Smith Contrib Zool 1994, 565:1-193.

52. Bath $\mathrm{H}$ : Verwandtschaftliche beziehungen der arten der gattung Hypsoblennius Gill 1861. Senck Biol 2000, 80:175-187.

53. George A, Springer VG: Revision of the clinid fish tribe Ophiclinini, including five new species, and definition of the family Clinidae. Smith Contrib Zool 1980, 307:1-31.

54. Stepien CA, Rosenblatt $\mathrm{RH}$ : Patterns of gene flow and genetic divergence in the Northeastern Pacific Clinidae (Teleostei: Blennioidei), based on allozyme and morphological data. Copeia 1991, 1991:873-896.

55. Hubbs C: Additional records of clinid fishes, with the description of a new species of Cryptotrema from the Gulf of California. Copeia 1954, 1:17-19.

56. McCosker JE, Stephens JS, Rosenblatt RH: Cottoclinus canops, a new genus and species of blenny (Perciform: Labrisomidae) from the Galápagos Islands. Proc Cal Acad Sci 2003, 54:155-160.

57. Böhlke JE, Springer VG: A new genus and species of fish (Nemaclinus atelestos) from the western Atlantic (Perciformes: Clinidae). Proc Acad Nat Sci Philad 1975, 127:57-61.

58. Baldwin C, Robertson R: A new Haptoclinus blenny (Teleostei, Labrisomidae) from deep reefs off Curaçao, southern Caribbean, with comments on relationships of the genus. ZooKeys 2013, 306:71-81.

59. Stephens JS, Springer VG: Clinid fishes of Chile and Peru, with description of a new species, Myxodes ornatus, from Chile. Smith Contrib Zool 1974, 159:1-23.

60. Springer VG: Systematics and zoogeography of the clinid fishes of the subtribe Labrisomini Hubbs. Publ Inst Mar Sci Univ Tex 1959, 5:417-492.

61. Hubbs C: Revision and systematic position of blenniid fishes of the genus Neoclinus. Copeia 1953, 1953:11-23. 
62. Cuvier G, Valenciennes A: Histoire naturelle des poissons. Paris: De l'imprimerie de Regnaud Chaudiere; 1836.

63. Rosenblatt RH, Taylor LR Jr: The Pacific species of the clinid fish tribe Starksiini. Pac Sci 1971, 25:436-463.

64. Fishelson L, Baldwin CC, Hastings PA: Gonad morphology, gametogenesis, and reproductive modes in fishes of the tribe Starksiini (Teleostei, Blenniiformes). J Morph 2013, 274:496-511.

65. Rosenblatt RH, Parr TD: The Pacific species of the clinid fish genus Paraclinus. Copeia 1969, 1969:1-20.

66. Brooks MJ: The ontogeny and evolution of sexual dimorphism in paradinin blennies (Teleostei, Labrisomidae). Tucson: University of Arizona; 1992.

67. Springer VG: The taxonomic status of fishes of the genus Stathmonotus, including a review of the Atlantic species. Bull Mar Sci 1955, 5:66-80.

68. Eschmeyer WN: Catalog of the Genera of Recent fishes. San Francisco: California Academy of Sciences; 1990.

69. Nelson JS: Fishes of the World. 2nd edition. New York: John Wiley \& Sons; 1984

70. Stephens JS: A revised classification of the blennioid fishes of the American family Chaenopsidae. Univ California Publ Zool 1963, 68:1-165.

71. McDade LA: Hybridization and phylogenetics: Special insights from morphology. In Phylogenetic Analysis of Morphological Data. Edited by Wiens J. Washington DC: Smithsonian Institution Press; 2000:146-164.

72. Rosenblatt R, Stephens J: Mccoskerichthys sandae, a new and unusual chaenopsid blenny from the Pacific coast of Panama and Costa Rica. Los Angeles County Mus Contrib Sci 1978, 293:1-22

73. Stephens JS: Seven new chaenopsid blennies from the western Atlantic. Copeia 1970, 1970:280-309.

74. Lin $\mathrm{H}-\mathrm{C}$, Hastings PA: Evolution of a Neotropical marine fish lineage (Subfamily Chaenopsinae, Suborder Blennioidei) based on phylogenetic analysis of combined molecular and morphological data. Mol Phyl Evol 2011, 60:236-248

75. Eytan Rl, Hastings PA, Holland BR, Hellberg ME: Reconciling molecules and morphology: Molecular systematics and biogeography of Neotropical blennies (Acanthemblemaria). Mol Phyl Evol 2012, 62:159-173.

76. Near TJ, Eytan RI, Dornburg A, Kuhn KL, Moore JA, Davis MP, Wainwright PC, Friedman M, Smith WL: Resolution of ray-finned fish phylogeny and timing of diversification. Proc Natl Acad Sci 2012, 109:13698-13703.

77. Almada VC, Robalo Jl, Gonçalves EJ, Levy A, Patzner RA: Blennies in temperate seas. In The Biology of Blennies. Edited by Patzner RA, Gonçalves EJ, Hastings PA, Kapoor BG. Enfield: Science Publishers; 2009:119-135.

78. Stepien CA: Evolution and biogeography of the Clinidae (Teleostei: Blennioidei). Copeia 1992, 1992:375-392.

79. Dercourt J, Zonenshain LP, Ricou LE, Kazmin VG, Le Pichon X, Knipper AL, Grandjacquet C, Sbortshikov IM, Geyssant J, Lepvrier C, et al: Geological evolution of the Tethys belt from the Atlantic to the Pamirs since the Lias. Tectonophysics 1986, 123:241-315.

80. Adams C, Gentry A, Whybrow P: Dating the terminal Tethyan event. In Reconstruction of Marine Paleoenvironments. Edited by Meulenkamp JE. Hoogeveen: Utrecht Micropalaeontological Bulletins; 1983:273-298.

81. Bellwood DR, Wainwright PC: The history and biogeography of fishes on coral reefs. In Coral Reef Fishes. Edited by Peter FS. San Diego: Academic Press; 2002:5-32

82. Briggs JC, Bowen BW: Marine shelf habitat: Biogeography and evolution J Biogeogr 2013, 40:1023-1035.

83. Burridge C: Antitropicality of Pacific fishes: Molecular insights. Env Biol Fish 2000, 65:151-164.

84. Levy A, von der Heyden S, Floeter SR, Bernardi G, Almada VC: Phylogeny of Parablennius Miranda Ribeiro, 1915 reveals a paraphyletic genus and recent Indo-Pacific diversification from an Atlantic ancestor. Mol Phyl Evol 2013, 67:1-8.

85. Briggs JC: A monograph of the clingfishes (Order Xenopterygii). Stanford Ichthy Bull 1955, 6:1-224.

86. Springer VG: Revision of the circumtropical shorefish genus Entomacrodus (Blenniidae: Salariinae). Proc U S Natl Mus 1967, 122:1-150.

87. Floeter SR, Rocha LA, Robertson DR, Joyeux JC, Smith-Vaniz WF, Wirtz P, Edwards AJ, Barreiros JP, Ferreira CEL, Gasparini JL, et al: Atlantic reef fish biogeography and evolution. J Biogeogr 2008, 35:22-47.

88. Fukao R: Fishes of Neoclinus bryope species complex from Shirahama, Japan, with description of two new species. Jap J Ichthy 1987, 34:291-308.

89. Drummond A, Ashton B, Buxton S, Cheung M, Cooper A, Duran C, Field M, Heled J, Kearse M, Markowitz S, et al: Geneious, 5.4 edn; 2011.
90. Brandley M, Schmitz A, Reeder T: Partitioned Bayesian analyses, partition choice, and the phylogenetic relationships of scincid lizards. Syst Biol 2005, 54:373-390.

91. Saccone C, Pesole G, Preparata G: DNA microenvironments and the molecular clock. J Mol Evol 1989, 29:407-411.

92. Swofford DL: PAUP*: Phylogenetic analysis using parsimony (and other methods). 4.0 Beta edn. Sunderland, MA: Sinauer Associates; 2002.

93. Akaike H: A new look at the statistical model identification. IEEE Trans Aut Contr 1974, 19:716-723.

94. Guindon S, Gascuel O: A simple, fast, and accurate algorithm to estimate large phylogenies by maximum likelihood. Syst Biol 2003, 52:696-704.

95. Posada D: jModelTest: Phylogenetic model averaging. Mol Biol Evol 2008, 25:1253-1256

96. Zwickl DJ: Genetic algorithm approaches for the phylogenetic analysis of large biological sequence datasets under the maximum likelihood criterion. PhD thesis. Austin: The University of Texas; 2006.

97. Miller MA, Pfeiffer W, Schwartz T: Creating the CIPRES Science Gateway for inference of large phylogenetic trees. In Proceedings of the Gateway Computing Environments Workshop (GCE). New Orleans. ; 2010:1-8.

98. Tavaré S: Some probabilistic and statistical problems in the analysis of DNA sequences. Am Math Soc: Lectures on mathematics in the Life Sciences $1986,17: 57-86$

99. Huelsenbeck JP, Ronquist F: MRBAYES: Bayesian inference of phylogeny. Bioinformatics 2001, 17:754-755

100. Ronquist F, Huelsenbeck JP: MrBayes 3: Bayesian phylogenetic inference under mixed models. Bioinformatics 2003, 19:1572-1574.

101. Drummond A, Rambaut A: BEAST: Bayesian evolutionary analysis by sampling trees. BMC Evol Biol 2007, 7:214.

102. Maddison WP, Maddison DR: Mesquite: a modular system for evolutionary analysis. $2.73 \mathrm{edn} ; 2011$

103. Drummond AJ, Ho SYW, Phillips MJ, Rambaut A: Relaxed phylogenetics and dating with confidence. PLOS Biol 2006, 4:e88.

104. Bellwood DR: The Eocene fishes of Monte Bolca: the earliest coral reef fish assemblage. Coral Reefs 1996, 15:11-19.

105. Blot J: Actinopterygii, Ordre des Scorpaeniformes? Famille des Pterygocephalidae Blot 1980. Studi Ricerche Giacimenti Terz. Bolca 1984 4:265-305.

106. Yu Y, AJ H, X-J H: RASP (Reconstruct Ancestral State in Phylogenies). 2.1 beta edn: 2013

doi:10.1186/1471-2148-13-210

Cite this article as: Lin and Hastings: Phylogeny and biogeography of a shallow water fish clade (Teleostei: Blenniiformes). BMC Evolutionary Biology 2013 13:210.

\section{Submit your next manuscript to BioMed Central and take full advantage of:}

- Convenient online submission

- Thorough peer review

- No space constraints or color figure charges

- Immediate publication on acceptance

- Inclusion in PubMed, CAS, Scopus and Google Scholar

- Research which is freely available for redistribution 